\title{
SÃO PAULO (1875-1975) $\left(^{\star}\right)$.
}

\author{
SUELY ROBLES REIS DE QUEIROZ \\ do Departamento de História da Faculdade de Filo- \\ sofia, Letras e Ciências Humanas da Universidade de \\ São Paulo.
}

\begin{abstract}
"O século que não despontara próspero e feliz, não findou, contudo, sem nos ver ressurgir de nosso próprio desfalecimento e sem conduzir-nos ao terreno da prosperidade do qual já divisamos um pouco o cenário promissor de um futuro melhor e não distante".
\end{abstract}

Assim se expressava Teodoro Sampaio, referindo-se a São Paulo, em artigo publicado a 16 de fevereiro de 1901 no jornal $O$ Estado de São Paulo.

Essa previsão embasava-se na evidência da superioridade econômica do Estado na época, cujos sintomas já se delineavam no último quartel do século XIX, mais precisamente a partir da década de 70 , justamente o início do período que pretendemos abordar.

Periodizar contudo a vida de São Paulo em um século é tarefa ingente e suscetivel de controvérsias, mormente em artigo limitado a uma visão geral, em que não cabe enfoque muito específico.

Poder-se-ia, utilizando marcos econômicos, considerar dois períodos nesse espaço de tempo: o primeiro corresponderia aos anos de 1870 a 1930, quando a expansão agrícola, tendo por base o café, tornou-se ali o mais significativo acontecimento, talvez, da história econômica do Brasil. E nessa fase que o planalto paulista, de hinterlândia esparsamente organizada se transforma no centro dinâmico da economia brasileira. O período seguinte, posterior à grande depressão, já evidenciaria a perda de expressividade do café como soberano mobili-


to do Centenário n ${ }^{\circ}$ " de $O$ Estado de São Paulo de 11/1/1975 (Nota da Redaçâo).
} 
zador de fatores de produção e de geração de renda no quadro da vida econômica paulista.

Haveria por certo quem preferisse, e ainda dentro de critérios econômicos, considerar esse século de vida em função do impulso industrializador notado a partir de 1930, apontando o período anterior como o de germinação das condições propiciadoras do fenômeno.

Poder-se-ia tambem utilizar marcos políticos, destacando como referencial a sincronia ou assincronia entre a representatividade econômica e política de São Paulo no cenário nacional. Dessa forma, caracterizar-se-ia São Paulo no período proposto em três etapas: a que corresponde à fase final do regime monárquico (1870-1889), quando a Província desponta como a principal do Império sem contudo dispor de representação equivalente na Corte; a que vai de 1889 a 1930 , período em que se observa como uma economia expansiva e dinâmica consegue usar com vigor e presteza o poder político em defesa de seus interesses e no reforço de uma hegemonia já então inconstestavel; e finalmente a etapa posterior à revolução de 1930, prolongada até a atualidade, quando a superioridade econômica, crescentemente distanciada da das demais unidades da Federação não é acompanhada com igual vigor pela atuação política em âmbito nacional.

Da análise da primeira fase, ou seja, a de 1870 a 1889 , ressalta o desequilíbrio entre o poder político e o econômico de São Paulo. A partir dos anos 70 a Província entraria em crescimento econômico acelerado mas sua participação política no governo imperial não corresponderia a tal ascensão. Basta lembrar em abono de tal afirmativa alguns dos dados oferecidos por Sérgio Buarque de Holanda em recente estudo sobre a representatividade política das províncias no governo imperial: até por volta de 1860 a Bahia era a mais influente representação provincial nos governos, seguida de Minas Gerais, Rio de Janeiro (incluindo o município da Corte) e Pernambuco. Dos trinta ministérios que se sucedem entre 1847, ano em que se cria a Presidência do Conselho, e 1889, ano final da monarquia, mais da terça parte é encabeçada por homens da Bahia.

Na composição desses ministérios a participação de São Paulo é reduzida em relação à de Províncias cujo empobrecimento econômico já se fazia notar visivelmente. Tomando por base a queda do gabinete Zacarias, em 1868, 14 governos conduziram o Império até a sua queda. Nestes, a Bahia terá 26 representantes o que corresponde a $20 \%$ do total de ministros. Minas Gerais concorrerá com 18 cabendo o terceiro lugar ao Rio de Janeiro que, com o Município Neutro, fornecerá 15, seguido de Pernambuco com 12. Em quinto lugar estariam São Paulo e Rio Grande do Sul, com 10 ministros cada um, o que mostra como a economia mais dinâmica não conseguiu prevalecer 


\section{$-421-$ \\ "sobre preferências regionalistas ditadas pela tradição" (1).}

No entanto, esse mesmo período acusa o acelerado desenvolvimento da economia paulista, ligada a uma multiplicidade de fatores interrelacionados e destacáveis somente para efeito de análise mas que, em última instância, decorriam da expansão agrícola baseada no café.

Com uma produção relativamente inexpressiva nas primeiras décadas, quando o açucar era a base econômica da Província, o café passa a ser o seu principal produto de exportação em meados do século (2) .

O primeiro grande cenário da lavoura cafeeira será o Vale do Paraiba, o chamado "norte", logo transformado em centro condensador de atividades agrícolas e de populaçāo. Alcançando o apogeu em meados do XIX, concorria em 1854 com $77,46 \%$ o de 3.534 .256 arrobas produzidas na Província, porcentagem que se reduziria a 19,99\% em 1886 (3).

Contudo o preço cada vez mais remunerador fomentava a expansão agrícola que, dado o carater predatório de que se revestia, reclamava a contínua abertura de terras novas. Outra grande zona se destacaria como produtora nessa fase: a do centro-oeste.

A experiência com a cultura da planta sedimentara conhecimentos que tambem favoreceram a rapidez do processo de substituição de engenhos de açucar em favor das lavouras cafeeiras naquela região. Campinas se converte em importante polo de disseminação do café que, em breve tempo, se irradiaria para todo o oeste da Província.

Fazendeiros daquele centro agrícola, de Itú, Jundiaí, partiam para a aquisição de terras novas, entravam pelos sertões do Tietê e seus afluentes, formavam lavouras no vale do Pardo e do Mogí-Guaçú, aproximavam-se das terras altas vizinhas de Minas em busca do solo roxo onde se verificavam prodigiosas colheitas. Essa corrente pioneira assinalaria a sua marcha através dos núcleos que pontilharam o Oeste, evidenciando os limites então alcançados pela cultura da planta na Província: Ribeirão Preto, fundada em 1870, Pirajú, em 1871, São

(1). - Sérgio Buarque de Holanda - "Do Império à República", História Geral da Civilização Brasileira, tomo II, vol. 5, p. 274, São Paulo, 1972.

(2). - Em 1850/51 a exportação de café pelo porto de Santos supera a do açucar (Cf. Maria Theresa Petrone, A lavoura canavieira em Sāo Paulo, São Paulo, 1969, p. 224).

Paulo, 1941.

(3). - Cf. Sérgio Milliet - Roteiro do café e outros ensaios, São 
José do Rio Preto em 1879, Campos Novos Paulista, São Manuel, Baurú, em 1880 (4).

Pode-se dizer que a conquista do Oeste, do imenso planalto interior onde o cafeeiro viria a conhecer a sua área propícia por excelência, pertence à segunda metade do século, mas é a partir de 1870 que se dá o grande surto da produção. Os dados oferecidos por Sérgio Milliet são expressivos: os $3 / 4$ da produção provincial em 1886 eram fornecidos pela região e assim distribuidos: $29 \%$ para a zona representada por Campinas e adjacências, chamada de zona central pelo autor e compreendendo os municípios de Jundiaí, Itatiba, Piracicaba, etc.; 23,69\% para a zona da Paulista, $21,81 \%$ para a Mogiana.

Essa contribuição refletir-se-ia na produção total da Província que entraria, então, em fase de franco enriquecimento.

Ainda no ano de 1870 São Paulo oferecia 437.580 sacas de 5 arrobas. Os quinquênios que se seguem acusam uma exportação que obedeceria à seguinte progressão: 1.644 .987 sacas de 60 quilos entre 1878 e $1883 ; 2.103 .657$ sacas entre 1883 e 1888 (5).

Em 1886 a produção teria sido, conforme Milliet, de 10.374.350 arrobas e apesar da discrepância notada entre as estatísticas mencionadas pelos diversos autores (6) o traço comum a todos é a insistência em acentuar o contínuo crescimento da produção e exportação cafeeiras. Se se tomar por base o ano de 1836, em que a lavoura se afirmava no Vale do Paraiba e considerando-se o ano de 1886, quase o final do período que ora analisamos, teria havido um aumento na proporção de $2.122,5 \%$ ( 7 ).

Em âmbito nacional, os $16 \%$ com que São Paulo contribuía em 1870 para a produção brasileira cresceram significativamente. Em 1885 a produção paulista correspondia a $40 \%$ da nacional (8).

(4). - Alice Canabrava - "A grande lavoura", Historia Geral da Civilizaçāo Brasileira, tomo II, vol. 4, São Paulo, p. 92.

(5). - Cf. Teodoro Sampaio, obra cilada.

(6) . - A flutuação das fontes em relação ao século XIX é razoavelmente grande. Enquanto Teodoro Sampaio (obra citada) aponta para o ano de 1870 uma produção de café da ordem de 567.652 sacas de 5 arrobas, Simonsen ("Aspectos da história econômica do café", Evoluçâo industrial do Brasil $e$ outros estudos, São Paulo, 1973, p. 194), refere-se a 437.580 sacas e Alfredo Ellis Júnior ( $O$ café e a Paulistânia), insiste em 1.043.112. O ano de 1886 oferece o mesmo problema: Sérgio Milliet fala em 10.374.350 arrobas e José Francisco de Camargo (Crescimento da população no Estado de Säo Paulo e seus aspectos econômicos, Boletim n⿳ 153 da Faculdade de Filosofia, Ciências e Letras da Universidade de São Paulo, São Paulo, 1952, volume 2, tabela 62), refere-se a 12.371 .613 arrobas.

(7). - Cf. J. F. Camargo, obra citada, vol. 2, tabela 62.

(8). - Roberto Simonsen, obra citada, p. 194. 
O surto de prosperidade decorrente do avanço e extensão das lavouras de café não teria certamente logrado tão consideravel impulso, não fora a presença de dois importantes fatores de êxito da empresa agrícola: a infra-estrutura de transporte representada pela criaçâao de ferrovias em período surpreendentemente rápido e a introduçāo em larga escala do imigrante europeu.

Esses dois fenômenos, ocorrendo justamente no Oeste paulista, estão ligados, a nosso ver, a outro fator grandemente significativo para o dinamismo que caracterizaria a região e o período que procuramos abordar. Referimo-nos à mentalidade e à visão modernizadora de seus homens de negócios, cafeicultores principalmente, que impulsionados pela idéia do lucro procuravam racionalizar a empresa agrícola em nivel mais capitalista, atirando-se ainda a empreendimentos que, a outros, menos afoitos, pareceriam arrojada aventura.

Essa atitude estaria provavelmente ligada à composição social dessas regiōes pioneiras para onde afluia uma população das mais diversas origens e profissões frequentemente sem qualquer tradição agrária: comerciantes, tropeiros, advogados, homens da cidade que se improvisavam lavradores e transpunham para o campo um contexto mental diferente. Não seria demais lembrar o nome de fazendeiros do Oeste, alguns dos quais já atuantes na primeira metade do século, cujas origens ou ação não se circunscreviam exclusivamente ao meio rural. E o caso por exemplo de Vergueiro que foi comerciante. Seu genro, Francisco Antônio de Sousa Queiroz, estudou em Coimbra, chegando a senador.

Antônio de Queiroz Telles e seu filho foram deputados provinciais enquanto José Elias Pacheco Jordão, fazendeiro em Rio Claro, formou-se em Direito em 1841, na Faculdade do Largo de São Francisco, desempenhando por algum tempo as funções de promotor público na Capital (9) .

Antônio de Lacerda Franco criaria uma firma corretora de café e seria senador bem como importante figura do Partido Republicano Paulista. Antônio da Silva Prado abriu pessoalmente fazendas no Oeste entre 1866 e 1889 , mas desempenhou o cargo de Ministro do Império atuando ainda destacadamente no incentivo à imigração e à abertura de estradas de ferro (10).

Aliás é sensivel a interpenetração de atividades da elite paulista, gerando às. vezes verdadeira concentração de funções. Exemplo? Aque-

(9) . - Cf. Richard Morse, Formação histórica de São Paulo, São

Paulo, 1970, p. Warren Dean, A industrialização de Säo Paulo, São Paulo, 1971, p. 51 . 
le apontado em recente estudo a respeito: o de Clemente Falcão de Sousa Filho, advogado, lente de Direito Civil da Faculdade, capitalista, proprietário, presidente das Companhias Paulista, de Águas e Esgotos, Estrada de Ferro São Paulo ao Rio de Janeiro, Gás e Oleos Minerais de Taubaté.

Sem jamais filiar-se a qualquer organização partidária, apesar de ser suplente de Delegado e de Juiz de Paz, era ainda protetor da Irmandade de São Benedito, provedor da Irmandade de Nossa Senhora da Glória, Conselheiro da Confraria de Nossa Senhora dos Remédios, irmão da Misericórdia e presidente do Club Haydn (11).

Examinando as listas de dirigentes da Santa Casa de Misericórdia de São Paulo para os anos de 1873, 1878, 1883 e 1884, uma vez que essa organização filantrópico-religiosa era mantida pelos elementos mais ricos e influentes da Província e confrontando-as com os dados fornecidos pelos Almanaques de São Paulo para os mesmos anos, a autora do já mencionado estudo, conclui que essa elite, profundamente integrada nas atividades da lavoura cafeeira, diversifica contudo o seu campo de investimentos, os quais, apesar de em ultima análise, reverterem em benefício da expansão do café, dirigem-se para atividades urbanas. A margem de risco que elas comportavam definiria uma mentalidade mais capitalista e inovadora.

Essas características talvez possam ser explicadas, como já foi mencionado, pela coexistência nas zonas pioneiras de elementos diversos quanto à composição social, ainda pelo itinerantismo que a perspectiva de solos roxos estimulava, favorecendo a mobilidade espacial e social propiciadora de atitudes inovadoras incomuns a áreas sedimentadas, de mais rígida estratificação social.

Por outro lado, a própria organização da propriedade cafeeira imbuida de carater comercial e monocultor (12), aumenta a necessidade de apelo aos centros urbanos que passam à função de distribuidores de mantimentos, estreitando as relações cidade-campo. O fazendeiro se torna absenteista, tipo mais citadino, para quem a propriedade agricola constitui primordialmente meio de vida e só eventualmente local de moradia ou recreio. Dessa forma,

"as receitas de bem produzir não se herdam pela tradição e pelo convívio, através de gerações sucessivas, com as terras de

(11). - Laima Mesgravis, A elite cafeicultora e a estrutura social paulista, (mimeografado).

(12). - A lucratividade determina a marcha do café no sentido de domínio soberano dos campos de cultura. Os demais produtos agrícolas como milho, feijão, farinha de mandioca, etc. afluiam à exportação em proporções cada vez menores. 
plantio, mas são aprendidas por vezes nas escolas e nos livros" (13).

Em decorrência nota-se nos fazendeiros maior flexibilidade para planificar a sua exploração agrícola dentro de um critério mais capitalista e ligado, evidentemente, à operação de um mercado lucrativo que recompensava os capazes e arrojados. Nessa perspectiva é possivel até admirar o realismo com que demonstravam fazerem parte de uma estrutura voltada para o mercado externo, concretizado no senso de oportunidade e na presteza com que acorriam aos ensejos que se lhes ofereciam.

Em 1861, por exemplo, no ano mesmo em que se inicia a guerra de secessão norte-americana,

"plantavam-se em São Paulo, as primeiras sementes de algodão herbáceo vindas dos Estados Unidos, visando ao abastecimento das fábricas inglesas, adaptadas ao produto de fibra curta e rapidamente a província toma o segundo lugar entre as áreas cotonicultoras do Brasil. Ao mesmo tempo, pievendo a volta do algodão dos Estados Unidos aos mercados de consumo passaram muitos produtores a empregar seus lucros na compra de equipamento de tecelagem $e$ as nove fábricas montadas ali até a queda da monarquia continuarão a ser aitamente proveitosas para esses empreendedores" (14).

As ferrovias seriam importante exemplo da manifestação desse espírito de empreendimento.

A cultura do café foi grandemente impulsionada nos sertões distantes pela rede ferroviária desenvolvida a partir dos anos 70 , rede de que a São Paulo Railway foi o tronco e a primeira na ordem cronológica. Os exportadores do Oeste, cuja produção se escoava por Santos exigiam uma ligação mais rápida e eficiente das terras do planalto com o litoral. A construção iniciada em Santos a 15 de maio de 1860 e em São Paulo a 21 de novembro do mesmo ano permititia a inauguração do tráfego entre as duas cidades no ano de 1865 e o funcionamento da linha inteira, até Jundiaí, o local mais próximo das zonas então grandes produtoras, na extensão de 139 quilômetros, no dia 8 de setembro de 1868 . Organizada com capitais ingleses, outras se lhe seguiram em rápida sucessāo e, desta vez, nacionais. A Companhia p. 169 .

(13). - Sérgio Buarque de Holanda, Raízes do Brasil, 4a ed., 1963. 273.

(14) . - Sérgio Buarque de Holanda, "Do Império à República", p. 
Paulista inauguraria a 11 de agosto de 1872 o trátego dos 43 quilômetros entre Jundiaí e Campinas, prolongando o traçado aberto pela Companhia Inglesa. No ano seguinte iniciava-se a colocação dos triIhos até Rio Claro, inaugurado o trátego para aquela cidade em agosto de 1876. A essa altura, o capital inicial dessa Companhia, de 5 mil contos de réis, fora dobrado, dispensando-se a garantia de juros fornecida pelo governo. Em 1881 atingia Descalvado, completando 281 quilômetros de vias férreas.

Em 1870 organizava-se a Companhia Ituana que inauguraria, três anos depois, o tráfego dos 70 primeiros quilômetros, ligando Jundiaí a Itú; pouco tempo após atingiria Piracicaba e São Pedro. Aproveitando um trecho navegavel dos rios Piracicaba e Tietê estabeleceu a Companhia Ituana uma linha de vapores entre Porto João Alfredo e Porto Martins, chamando assim para a sua zona de influência uma grande parte da produção dos ricos municípios de Botucatú, São Manuel e Lençois, na margem esquerda do Tietê, para onde fizera construir um ramal férreo, mais tarde ligado ao tronco da Sorocabana. Esta, criada em 1871, abria ao público em 1875 o tráfego entre São Paulo e Ipanema, prolongando-o posteriormente para os lados de Tietê, Botucatú, Tatuí, Boituva e Itapetininga .

Organizadas em 1872, a Bragantina e Mogiana visavam o território mineiro. A primeira, iniciando seus trabalhos somente em 1878, inaugurou o tráfego de sua linha ruma extensão de 52 quilômetros, em 1884, de Campo Limpo até Bragança, passando por Atibaia.

A Mogiana, sobrepondo-se ao traçado da velha estrada do Anhanguera, parte de Campinas em 1873, alcança Casa Branca em 1878 e chega a Ribeirão Preto em 1883, totalizando assim 368 quilômetros de vias férreas em um decênio. Em 1886 inaugurava o ramal que chegaria até Caldas, penetrando em território mineiro.

A Companhia Rio Claro objetivava a continuação dos trilhos que a Paulista parara naquela cidade e em 1886, quatro anos depois de criada, terminava a construção da linha principal até Araraquara, com ramais para Brotas, Dois Córregos e Jaú, numa extensão de 241 quilômetros.

Em 1872 organizava-se a Companhia São Paulo e Rio de Janeiro, a fim de ligar a Capital da Província a Cachoeira, ponto final do ramal de São Paulo da Estrada de Ferro Pedro II, e em 1877, os 231 quilômetros da estrada eram inaugurados.

Os dados citados acima mostram como a partir dos anos 70 as ferrovias penetram o Oeste, buscando as zonas produtoras de café, organizando-se em função da lavoura mas, a seu turno, agindo como fator altamente positivo no desenvolvimento dessa mesma lavoura. 
Em 1886 contava a Província 1.806 quilômetros de vias férreas já construídas e 406 em construção, podendo-se avaliar a importância da rede ferroviária paulista e a rapidez de sua instalação se se lembrar que as províncias de Minas e do Rio de Janeiro, tambem ligadas à exploração do produto vorazmente solicitado pelo mercado externo apresentavam na mesma época 1.310 quilômetros de trilhos colocados (15).

Empreendimento de paulistas, os 2.200 quilômetros existentes no fim de 1887 , representavam

"um capital superior a 100.000 contos, todo ele, com exceção apenas da Companhia Inglesa, nacional, e pela maior parte, senão na quase totalidade, paulista" (16).

A preocupação demonstrada com o transporte faria um presidente de Província exclamar:

"Estradas: É este o pedido que se ouve de todos os lados; é este o empenho de todos os espíritos" (17).

A atitude modernizadora dos fazendeiros do Oeste revelava-se ainda na introdução de métodos mais aperfeiçoados de cultivo, no emprego de inovações técnicas:

- "há três anos designavam-se as máquinas a vapor existentes na Província; hoje, só no Oeste, podem-se contar mais de $200 "$,

assinalaria o presidente Antônio da Costa Pinto e Silva em seu relatório de 5 de fevereiro de 1871 .

$\mathrm{Na}$ verdade demonstravam uma visão politizada do desenvolvimento econômico ao escolherem empreendimentos que o governo poderia conceder à guisa de monopólios, tais como estradas de ferro, serviços de utilidade pública, entre outros, que, revelados improfícuos, sempre poderiam ser encampados pelos poderes públicos.

Destacavam-se ainda como grupo diferenciado na compreensão da necessidade de substituir a mão-de-obra escrava: 1974.

(15). - Cf. Odilon Nogueira de Matos, Café e ferrovias, São Paulo,

(16). - Alberto Salles, A Pátria Paulista, Campinas, 1887, p. 148.

(17). - Relutório de Antônio Cândido da Rocha de 2 de fevereiro de 1870, São Paulo, 1870, p. 27. 
"Há cerca de vinte anos principiou a aparecer da parte de fazendeiros importantes da Província o desejo de aplicar à sua lavoura o trabalho livre".

notava o presidente de então (18).

O trabalho agrícola até ali baseado quase que exclusivamente na mão-de-obra escrava sofrera rude golpe com a extinção do tráfico negreiro. Percebendo de imediato a oportunidade da introdução do imigrante estrangeiro, procuraram os fazendeiros subsidia-la com recursos próprios da Província, uma vez que o Governo Imperial dispensava maiores atenções ao estabelecimento de núcleos coloniais, inspirado que fora em pensamentos teóricos e idealistas que visavam à pequena propriedade. Não interessava por certo ao fazendeiro um colono a cultivar produtos de subsistência em minifúndios cedidos ou comprados e sim uma mão-de-obra livre colocada a seu serviço, aumentando-lhe os lucros (19).

Nesse sentido é que devemos encarar as tentativas sob o regime de parceria, feitas pelos Senadores Vergueiro e Sousa Queiroz, alem de outros fazendeiros abastados que lhes seguiram o exemplo no período compreendido entre 1847 e 1867.

Por razões já conhecidas o sistema é abandonado mas a partir dos anos 70 e em função de fatores vários, entre os quais o encarecimento do escravo decorrente da extinção do tráfico e da alta mortalidade observada nessa população, bem como a perspectiva da abolição alentada pela lei emancipadora de 1871 , acentua-se a necessidade de substituir a mão-de-obra.

A solução dessa necessidade acorrem os elementos do Oeste, mais permeáveis ao abandono dos valores tradicionais (20), o que na ver-

(18). - Relatório de Antônio da Costa Pinto e Silva apresentado em 5 de fevereiro de 1871, São Paulo, 1871, p. 37.

(19) . - Em Relatório feito em 1887, manifestava o Barão de Parnaiba a opinião de que "a política dos núcleos coloniais deveria ser deixada ao Governo Geral que estava capacitado a fazer os adiantamentos necessários aos colonos durante os primeiros tempos e promover a feitura de estradas e outros melhoramentos, facilitando assim o trabalho aos imigrantes recém-chegados" (Cf. Emília Viotti da Costa, Da senzala à Colônia, São Paulo, 1966, p. 137).

(20). - E fato sabido que os fazendeiros de zonas mais antigas e sedimentadas como as do Vale do Paraiba mostravam-se infensos a mudanças, apegando-se a formas tradicionais de produçāo e ao trabalho escravo. Essas atitudes decorriam, em círculo vicioso, da queda de produção na região - a partir de 1880 especialmente as lavouras do Vale, em decadência, nāo ofereciam perspectivas de recuperação - e os agricultores não dispunham de capitais para melhorar o sistema de produção e para o pagamento de salários a trabalhadores livres, o que, a seu turno levava a maior queda da produtividade, e ao apego às formas tradicionais. As diferenças de atitudes en- 
dade significava uma atitude mais realista se se pensar que a imobilização de capital em escravos que tendiam a desaparecer era inconveniente ante as perspectivas de investimentos em novos setores.

Em 1870 Joaquim Bonifácio do Amaral, proeminente fazendeiro de Campinas vai à Europa a fim de, pessoalmente, contratar colonos para sua propriedade. Nesse mesmo ano o Diário de São Paulo estampava artigo em que analisava as novas possibilidades da imigração e frisava a abolição da escravidão nos paises civilizados (21) .

Os anos 70 marcam então o início da imigração assalariada, com muito maiores possibilidades de exito, quando se analisam os riscos desanimadores a que estava sujeito o colono enquanto dominou o sistema de parceria.

Com uma renda monetária dependente da produtividade das plantas a seu cargo e dos preços vigentes em Santos, o que o colocava à mercê das flutuações desses mesmos preços, não tinha nenhum controle sobre as fases posteriores à colheita, como a pesagem, processamento, seleção, transporte e venda. Essa impotência deixava o colono à inteira discrição do proprietário.

A mudança no método de remuneração seria significativa para o sucesso do sistema de trabalho livre em São Paulo (22). Enquanto na década de 1860 a 1869 entram 1.681 imigrantes na Província, no período de 1870 a 1879 acorrem 11.730 e na fase final do Império, 1880 a 1889 , o número foi de 183.979 (23).

tre os dois grupos refletiam-se na política provincial, quando as medidas solicitadas pelos grupos do Oeste eram obstadas pelos do Vale sob a alegação de onerarem os cofres públicos, confundindo interesses particulares com os da coletividade.

(21). - Cf. Emília Viotti da Costa, ob. cit., p. 188.

(22). - Defendendo a idéia de que o sucesso do trabalho livre em São Paulo deveu-se a "um padrão de incentivos econômicos positivos ao invés de um sistema conscientemente desenvolvido e eficaz de sançōes negativas", estudioso americano em recente trabalho discrimina as fontes de onde provinham os salários monetários do trabalhador livre, considerando ter a experiência da imigração alcançado exito em São Paulo, em grande medida, "por causa da forma de trabalho nas plantaçōes de café e não a despeito disso" (Thomas H. Holloway - "Condições do mercado de trabalho e organizaçāo do trabalho nas plantaçōes na economia cafeeira de São Paulo, $1885 / 1915$ - uma análise preliminar", Estudos Econômicos, vol. 2, n̊ 6, São Paulo, dez. 1972).

(23). - Sálvio Azevedo - "Imigração e colonização no Estado de São Paulo", Revista do Arquivo Municipal de São Paulo, São Paulo, 1941, vol. 75. Até os anos 70, São Paulo recebera fracos contingentes imigiatórios: no período compreendido entre 1827 e 1886 vieram 53.104 estrangeiros e, desses, 41.930 entraram entre 1875 e 1886 (Cf. Camargo, ob. cit., I, p. 115). 
Em consonância com o sistema de remuneração estabelecido para uma cultura que a cada dia se tornava mais lucrativa o governo provincial procuraria dinamizar os empreendimentos particulares.

Justificando a atividade que o governo deveria desenvolver nesse sentido diria o presidente Costa Pinto:

— "... procurar substituir convenientemente os elementos de trabalho é dever não só dos poderes públicos como de todo cidadão" (24).

$\mathrm{E}$ adiante, referindo-se aos investimentos oficiais:

- "o Estado porem, fazendo essas despesas, parecendo perde-las só tem a lucrar. O que produz, o que consome o colono, dá margem larga para pela cobrança dos impostos, indenizar-se o Estado do que dispendeu" (25).

O decreto de 8 de agosto de 1871 constituiria a Associação Auxiliadora de Colonização que, composta de fazendeiros e capitalistas, receberia em 1874 colaboração mais efetiva do Governo Provincial através de subvenção para financiamento da passagem de imigrantes (26).

Novos créditos são concedidos à imigração em 1881 e 1884 mas é a partir de 1886 que a corrente imigratória se avoluma de modo consideravel, em função de outra série de medidas tomadas pela administração. Nesse ano ascenderia à presidência da Província o Barão de Parnaiba, Antônio Queiroz Teles. Abastado fazendeiro no Oeste, capitalista, participante das grandes iniciativas da época, desde logo identificara-se com a política imigratória. Não poderia a lavoura cafeeira paulista ter escolhido melhor representante junto à administração pública:

- "Executivo e Legislativo harmonizaram-se então, embora o primeiro pertencesse ao Partido Conservador e a maioria do segundo fosse constituida pelos liberais, para a solução final do grande problema que vinha preocupando a Província- a importação de braços livres que não somente viessem preencher os claros que a iminência da abolição da escravatura ameaçava

(24). - Relatório provincial de 5 de fevereiro de 1871, p. 37 .

(25). - Idem, p. 38.

(26) . - Relatório do Presidente Joāo Teodoro em 5 de fevereiro de 1874. anexo 12, São Paulo, 1874. 
deixar no serviço da lavoura mas que tambem viessem imprimir novos rumos à agricultura paulista" (27).

Medidas essenciais empregou a administração Parnaiba: aplicar generosamente os recursos financeiros da Província nos serviços da imigração e confia-los à associação que ainda naquele ano de 1886 se fundara: a Sociedade Promotora de Imigração que, tendo à frente Martinho Prado Júnior, Nicolau de Sousa Queiroz, Rafael de Aguiar Pais de Barros e outros, não se limitaria à propaganda mas enviaria agentes à Europa, celebrando contratos para a introdução em massa de imigrantes.

Nessa mesma época criar-se-ia a Hospedaria de Imigrantes, com capacidade para receber inicialmente quatro mil imigrantes, alimenta-los durante oito dias e auxilia-los no encaminhamento para a lavoura.

Os resultados de tais medidas não se fizeram esperar: se, de acordo com os dados fornecidos por Sálvio de Azevedo a média de chegada de imigrantes entre 1860 e 1869 foi de 168,1 por ano, e na década seguinte de 1.173, no período compreendido entre 1880 e 1889 aumentou para 18.397,9. Contudo, essa última média foi de tal forma reforçada, pelas entradas dos quatro últimos anos a contar de 1886, pois ainda em período imediatamente anterior, ou seja, entre 1883 e 1885 inclusive, teriam chegado 17.433 (28). No entanto, só em 1887, chegariam 34.710 (29) e no ano seguinte, $92 \mathrm{mil}$, continuando a corrente a avolumar-se no período republicano.

O crescimento do fluxo migratório tem reflexos, a par de outros fatores, em dois fenômenos: no aumento da população e em relação à questão servil.

Na medida em que o trabalho realizado com a mão-de-obra livre revelava-o mais rentavel, não só quanto à produtividade individual do colono como quanto à racionalidade do sistema, de vez que o trabalhador livre, ganhando a condição efetiva de mercadoria, fortalecia as condições racionais indispensáveis à produção crescente de lucro, au-

(27) . - Nícia Vilela Luz - "A administração provincial de São Paulo em face do movimento abolicionista", Revista de Administração, $n^{\circ} 8$, dezembro de 1948, p. 87 .

(28). - Destes, 9.050 eram italianos e 5.714 portugueses num total de 14.764. Dos restantes, o grupo mais numeroso era de espanhois, seguido em nível bem inferior por alemães, austríacos franceses, suecos ... (Cf. Alberto Salles, ob. cit. p. 137).

(29) . - Era Săo Paulo que atraia os imigrantes. Os 34.710 recebidos em 1887 representavam alta porcentagem em relação ao total recebido pelo Brasil nesse ano: 54.990 imigrantes (Cf. Teodoro Sampaio, op. cit.). 
mentou o entusiasmo pela imigração e, consequentemente, enfraqueceu-se a persistência na manutenção da mão-de-obra escrava.

Até o terceiro quartel do século XIX a economia da Província baseara-se quase que exclusivamente no trabalho do cativo. Tornara-se este indispensavel a partir do final do século XVIII, quando São Paulo, através do açucar, integra-se em uma economia de mercado.

O café contaria desde logo com a mão-de-obra africana ou de ascendência africana, exigindo crescente importação, a princípio da África e, cessado o tráfico externo, das regiões brasileiras que pudessem oferece-la, concentrando-se a escravaria especialmente no Vale do Paraiba e tambem em algumas zonas do Oeste, especialmente Campinas, Piracicaba, Mogí-Mirim, Rio Claro, Limeira. As zonas mais novas de cultivo, abertas a partir dos anos 70 , como Ribeirāo Preto, por exemplo, buscarāo solução para o problema da mão-de-obra no braço livre.

Contudo, até essa época era o escravo o trabalhador das zonas economicamente importantes; basta lembrar que em 1854 as fontes acusam uma população cativa de 117.238 cativos e em 1871 esse número havia aumentado para 173.267 (30).

As leis emancipadoras, especialmente a do ventre-livre, promulgada em 1871, apesar de representarem soluçōes contemporizadoras, não deixariam de ter seus efeitos, pois chamando a atenção para a inexorabilidade do processo de extinção da escravidão, levariam não só as zonas mais dinâmicas a reafirmarem sua posição de incentivo à mão-de-obra livre, cujo sucesso por sua vez, reforçava a posição anti-escravista, como tambem a manifestaçōes da "liberalidade", nāo só pública como particular, no tocante à alforria de escravos .

A primeira, far-se-ia através do Fundo de Emancipação, criado já com a lei de 1871 e que previa, em cada província do Império, a libertação anual de tantos escravos quantos correspondessem à quota destinada pelo Fundo, a qual provinha de vários tributos.

Pouco efeito teve no entanto o Fundo no sentido de aumentar o número de manumitidos em São Paulo: em 1878, sete anos depois de promulgada a lei, foram alforriados 364 escravos em 78 municípios (31), o que corresponderia a uma média de 4 por município naquele ano.

(30). - Apud Joaquim Floriano de Godoy, O elemento servil $e$ as Cámaras Municipais, Rio de Janeiro, 1887, p. 229/30.

p. 63 .

(31). - Relatório do Presidente da Província ao Barão de Três Rios, 
De 2 de setembro de 1885 a 5 de fevereiro de 1886 o Fundo libertaria 132 escravos, o que, por estimativa, equivaleria ao total de 396 por ano (32).

Quanto à liberalidade particular foi reconhecidamente mais efetiva, mas ocorria com maior frequência em zonas onde o braço escravo não fosse tão vital. Em seu relatório de 5 de fevereiro de 1886, o Conselheiro João Alfredo de Oliveira lembrava que até 30 de junho de 1885 a Província libertara 11.131 escravos a título gratuito. $O$ município onde ocorrera maior número de manumissōes gratuitas fora o da Capital, com 1.036 libertações.

Os municípios mais antigos no entanto apegavam-se tenazmente à tradição escravista, opondo-se com energia às medidas atenuadoras: Campinas era tida como a região onde reconhecidamente mais dificil se apresentava a alforria de um escravo e quando esta ocorria, era sempre restritiva, condicionada à prestação de serviços. Assim é que, no período de $1^{\circ}$ de maio de 1886 a 30 de março de 1887 , esse município alforriou 251 cativos, mas sujeitou 248 deles à prestação de serviços. Rio Claro libertou 75, todos obrigados; Taubaté, 68, tambem obrigados; idem Lorena com 55 e Bananal 417, dos quais 414 condicionados à prestação de serviços (33). Até essa época o índice de população escrava no Vale do Paraiba era da ordem de $8,5 \%$, com 28.556 cativos enquanto no Oeste mais antigo, representado por Campinas e adjacências o índice era de 10,5\% com 31.184 escravos.

Mesmo as zonas relativamente novas do Oeste como Rio Claro, Araras, Araraquara, Descalvado. Limeira, São Carlos, desenvolvidas após a $1^{\text {a }}$ metade do século, ainda apresentavam significativo índice de população cativa .

Mas a falta de garantia para a propriedade escrava cresceria e atingiria São Paulo em face do fato praticamente consumado da abolição. A administração provincial já o compreendera procurando cercear o desenvolvimento da escravatura na Província e com isso evitar - a desorganização do trabalho e da produção, salvaguardando ao mesmo tempo os interesses da grande propriedade rural.

Para tanto procurou coibir a importação, gravando-a com impostos. Estabelecido em 1878 o imposto de um conto de réis sobre cada escravo importado de outras províncias, os fazendeiros escravistas liderados pelo Clube da Lavoura de Campinas, prestigiosa agremiação da

(32). - Relatório de Joäo Alfredo de Oliveira em $5 / 2 / 1886$, p. 43.

(33). - Manuscrito do período imperial (1883/1888) existente no Departamento do Arquivo do Estado de São Paulo sob o rótulo Escravos, cx. 2. 
época, levantaram tão grande clamor que a medida deixou de ser posta em prática.

Mas em 1881 a entrada de escravos seria drasticamente coibida, mediante o imposto de dois contos de réis sobre escravo importado que, naquele momento, dada a rápida intensificação da propaganda abolicionista, conseguiu ser aprovado e mantido.

$\mathrm{Na}$ verdade, a partir dessa época é que a Província, até então infensa ao clamor abolicionista, cederia à pressão que em poucos anos a avassalou. A despeito da incansavel atuação de um Luís Gama, que, com ardorosa ação conseguira libertar mais de quinhentos escravos, ainda ao tempo de sua morte, em 1882, segundo os contemporâneos, São Paulo

"podia ser chamada com razão a Virgínia do Brasil, tão cheia estava da escravatura descida do Norte e paga por muito bom dinheiro" (34).

O movimento abolicionista explodiu praticamente nos anos 80 e em rápido espaço de tempo engolfou a Província.

Para tanto, teriam contribuido as modificação observadas já na década de 70, algumas delas já mencionadas: as estradas de ferro, diminuindo as distâncias e facilitando as comunicações difundiam idéias e opiniōes veiculadas nos centros urbanos. Estes, fortalecidos por tais empreendimentos e outras melhorias, abrigariam uma população já de certa forma desvinculada dos interesses escravistas e, portanto, mais permeavel à ação daqueles que lutavam pela extinção do braço escravo, incluida nesse caso a Imprensa abolicionista que orientava a opinião pública estimulando-lhe a adesão.

Organizações ostensivamente revolucionárias como a dos Caifazes de Antônio Bento insuflam a fuga de escravos, promovendo o abandono em massa das fazendas e mais ainda: recolocando esses escravos, já como trabalhadores livres, nas lavouras onde a necessidade de mão-de-obra era premente.

Diante de uma realidade inexoravel e, somente nos últimos anos, notar-se-ia consideravel aumento das alforrias e consequente diminuição da população escrava.

(34). - Evaristo de Morais, A campanha abolicionista, Rio de Janeiro, 1924 , p. 260 . 
Em 1871 havia 173.267 cativos e em fins de novembro de 1884 ainda perduravam 167.491 (35), mas em 1886 reduzira-se o número para 107.329 (36). Diminuiria em proporção geométrica daí para frente, forçando as zonas escravistas a curvar-se ante a inexoravel realidade que tomaria expressão legal a 13 de maio de 1888 .

Nesse ínterim, em sincronia com a expansão da lavoura cafeeira e em decorrência da corrente imigratória cresceria continuamente a população de São Paulo.

O recenseamento de 1872 , realizado pelo Governo Geral e abrangendo todo o país coloca a população de São Paulo em 4 o lugar em relação à das demais províncias, concedendo a Minas Gerais, Bahia e Pernambuco os $1^{\circ}, 2^{\circ}$ e $3 .^{\circ}$ lugares respectivamente; a população paulista livre era de 680.742 habitantes que, somados a 156.612 escravos totalizavam 837.354 indivíduos, pouco menos do triplo do que se recenseara em 1822, por ocasião da Independência .

Até aquela época, a economia definida pela agricultura era escravista: dos 89 municípios paulistas recenseados, os que apresentam maior número de cativos são justamente os de lavoura cafeeira. Campinas, por exemplo, tem 13.685 escravos para 17.712 livres, o que representa uma porcentagem de $40 \%$ de escravos em relação ao total da população.

Bananal, grande região cafeeira, possuia 7.325 habitantes livres e 8.281 escravos, numa porcentagem de $53 \%$ de cativos.

Outros municípios cafeeiros eram tambem grandes celeiros de escravos, como se pode depreender da seguinte tabela:

\section{LIVRES}

1. - Mogí-Mirim (abrangendo MogíGuaçú e Espí-ito Santo do Pinhal)

2. - Constituição (Piracicaba) .....

3. - Taubaté ................

4. - Pindamonhangaba $\ldots \ldots \ldots$.

5. - Guaratinguetá

\subsection{2}

10.611

16.725

10.918

16.485

\section{ESCRAVOS}

5.006

5.142

4.122

3.718

4.352

(35). - Cf. Alves Motta Sobrinho, A civilização do café, São Paulo, 1967, p. 109/110. "Ao redor de 56 mil escravos estavam localizados no vale do Paraiba, sendo que Bananal e Guaratinguetá compareciam com os maiores estoques. Em todos os 112 municípios paulistas só Campinas e Piracicaba (incluindo São Pedro), possuiam mais escravos.

(36) . - Relatório do Visconde de Parnaiba em 19/11/1887, São Paulo, 1887, p. 43. 
Os municípios não cafeeiros por outro lado têm pequena população cativa, a despeito de serem, por vezes, densamente povoados. E o caso da Capital que, com suas nove freguesias possui em 1872 a maior população da província: 27.557 habitantes livres e 3.828 escravos, $10 \%$ aproximadamente em relação ao total de sua população. Santos tambem com pequena função agrícola, tem 7.585 pessoas livres e 1.606 escravos.

A intensificação da corrente imigratória aumentaria rapidamente a distância entre população livre e escrava. Aquela atingiria especialmente as zonas cafeeiras mais novas. Foram elas que se beneficiaram do grande surto posterior a 1886 ,

"tirando partido das condiçōes econômicas, particularmente da alta produtividade dos cafezais" (37).

e acentuando crescentemente as diferenças entre o Vale do Paraiba e o Oeste.

Em seu conjunto é sincrônico o desenvolvimento da população e da cultura cafeeira no período abordado. Basta lembrar que entre 1854 e 1886 a produção do café aumentou de $228,9 \%$ e a população de $185,1 \%$ (38).

Em 1887 São Paulo contava 1.221.380 habitantes, acusando um aumento de $192,8 \%$ em relação ao total de 54 e de $329,6 \%$ relativamente ao de 1836 (39).

As transformações observadas a partir de 1870 refletem-se concretamente em uma série de mudanças. O binômio café-ferrovias, por exemplo, promove a urbanização e modernizaçāo de alguns núcleos, especialmente o da Capital que até então conservara a sua importância em função sobretudo da posição geográfica, assentado que estava a montante de uma estrela de caminhos, num centro de circulação fluvial e terrestre. Machado de Oliveira já o assinalava em 1862 ao escrever:

"Sendo esta cidade o ponto que está em majs contato com a serra de Paranapiacaba, na parte em que através desta corre a estrada que desemboca no lito:al de Santos, concentra em si as estradas que vêm do interior da Província em todos os rumos

(37). - Emília Viotti da Costa, ob. cit., p. 212.

(38). - J. F. Camargo, ob. cit., I, p. 165.

(39). - Idem, p. 168 . 
de hemiciclo setentrional, o que aumenta a importância que lhe dá a categoria de capital" (40).

A pequena e provinciana cidade custaria a modernizar-se (41). Seus edifícios públicos eram pequenos, feios e pobres, as habitaçōes de taipa ostentavam as rótulas por onde reclusas mulheres aliviavam o tédio de uma vida monótona espiando as ruas mal calçadas onde raros transeuntes circulavam.

As novas ferrovias seriam os precipitantes de um processo que em breve tempo modificaria a feição da cidade; encurtando distâncias, facilitariam uma mobilidade espacial que influiria nos hábitos de observação das populações, provocando comparações e reinvindicações que atuariam positivamente para a modernização. Com o privilégio da ligação ferroviária para Santos, e o estímulo decorrente de crescente implantação de trilhos a oeste, desenvolveu-se o comércio de São Paulo, tornada agora o centro de escoamento das riquezas destinadas à exportação e das mercadorias importadas de que a Província necessitava.

No início da década de 70 a função econômica que a cidade assumiria ainda não se evidenciava claramente: um almanaque de 1873 arrolava no setor empresarial alem das Companhias de Estradas de Ferro, dois Bancos particulares que concorriam com as Caixas Filiais do Banco do Brasil e do Banco Mauá e com os capitalistas particulares.. Existiam ainda a Companhia de Seguros Marítimos e a Companhia de Carris de Ferro de São Paulo.

O setor comercial contava 13 casas comissárias e inúmeras lojas destinadas à venda de fazendas, roupas, armarinho, ferragens, calçados, louças e secos e molhados.

A vida sócio-cultural era destituida de grande expressão. Havia alem das instituições de ensino oficial, oito colégios particulares de nacionais, 1 escola americana e 2 alemãs, todos dedicados ao ensino primário e secundário. época.

Quatro associaçōes recrativas reuniam a sociedade paulista da

Já se observava contudo o desenvolvimento de uma mentalidade urbana favorecida tambem pela interação cidade-campo decorrente do sentido monocultural que tomou a lavoura cafeeira. Como assinalou Pierre Monbeig,

(40). - Apud Odilon Nogueira de Mattos, "A cidade de São Paulo no século XIX", Rèvista de História no 21, São Paulo, 1954, p. 109.

$\therefore$ (41). - Segundo Taunay, Campinas tinha em 1865 um aspecto mais atraente que Sāo Paulo (Cf. Richard Morse, ob. cit., p. 172). 


\begin{abstract}
"as demoras nos domínios rurais começavam a encurtar; a casa rural perdia em austeridade o que ganhava em elegância para estadas confortáveis; mas ao mesmo tempo, a casa da cidade passava a ser a residência principal, objeto de todos os cuidados, manifestação exterior da riqueza do seu proprietário. A formação de empresas capitalistas modernas, as necessidades de sua gestão eram incompativeis com o gênero de vida tradicional. A ruptura do círculo estreito da velha economia paulista, a evolução social que a acompanhou - tais foram os fatores da urbanização da classe dirigenten (42).
\end{abstract}

Sinal seguro dessa mentalidade urbana seria a administração de João Teodoro Xavier de Matos, merecedora da atenção de um historiador que a consideraria mesmo o período de "segunda fundação da cidade" (43).

Governando no período compreendido entre 1872 e 1875 destinou metade do orçamento anual da Província ao embelezamento da cidade e a melhorias materiais.

Os resultados tornaram-se rapidamente visíveis: 1872 marca $\circ$ início da iluminação a gás, cujo número de lampiōes, inicialmente 606 , estava mais do que duplicados em 1887. As ruas que formavam o triângulo central da cidade receberam paralelepípedos em 1873; a várzea do Carmo foi drenada e o Instituto Vacínico criado em 1874. A taipa, por feia e rústica, foi sendo substituida e assim tambem as rótulas. A partir de 1872 a cidade passou a contar com um serviço de bondes a tração animal, cuja primeira linha ligou o centro à Estação da Luz. Em 1877 inaugurava-se a linha do Brás, com ponto terminal na Estação do Norte.

Não se poderia considerar esses acontecimentos como simplesmente provocados por um determinismo econômico. Outras condicionantes de um processo histórico seriam tambem responsáveis. Lembramo-nos, a propósito, da observação de Eugênio Egas:

- "Uma febre de progresso rápido, constante e seguro apodera-se dos paulistas. Eles querem que a sua capital seja uma cidade procurada por todos, nacionais e estrangeiros, que se tor-

(42). - Pierre Monbeig, "Aspectos geográficos do crescimento de São Paulo", O Estado de São Paulo, no especial de 25/1/1954.

(43). - Eurípedes Simões de Paula, "A segunda fundação de São Paulo. Da pequena cidade à grande metrópole de hoje", Revista de História no 17 , São Paulo, 1954. 
ne um centro, um grande empório do comércio, indústria e arte" (44).

Em 1876 organizou-se a Associação Auxiliadora do Progresso da Província, constituída pelas pessoas gradas da cidade, e cuja primeira iniciativa foi a criação do Museu Provincial de História Natural, núcleo inicial do futuro Museu do Ipiranga .

Dos empreendimentos e melhorias que se multiplicam não poderia estar ausente a Imprensa, refletindo em suas páginas a definição de campos políticos e em alguns casos tornando-se o porta-voz de reinvindicações ansiadas. Inúmeras publicações surgiram nessa época decorrentes da agitação causada pelo Manifesto Republicano de 1870 e pela multiplicação de pronunciamentos a respeito da questão servil. A maioria contudo, de vida efêmera como foi o caso de $A$ Crença, $O$ Tribuno, A Coruja, para só citar alguns. Outros, contudo, desafiariam os tempos e chegariam aos nossos dias como o Correio Paulistano, atuante até há algum tempo atrás e sobretudo A Província de São Paulo, que com o nome de $O$ Estado de São Paulo é hoje dos mais importantes órgãos de imprensa do Brasil e do continente sul-americano. A necessidade de um jornal que,

"não sendo republicano extremado, viesse discutir com serenidade os absorventes problemas do momento",

levou em 1875 à constituição de uma sociedade em comandita que, não tendo conseguido comprar o Correio Paulistano adquiriu uma tipografia à rua do Palácio, 14, hoje Rua do Tesouro. Sob a orientação de Rangel Pestana e Américo de Campos, entre outros, o novo diário foi o iniciador da venda avulsa de jornais e ostentava dois dísticos programáticos:

"Colunas franqueadas aos escritos de utilidade pública" e "Liberdade de pensamento e responsabilidade do autor" (45).

O "burgo de estudantes" (46), cuja vida gravitava em torno da Faculdade de Direito do Largo de São Francisco, a cidade que tinha 469 .

(44) . - Eugênio Egas, Os Municípios paulistas, São Paulo, 1923, I, p.

(45) : - Cf. Nelson W. Sodré, A História da Imprensa no Brasil, Rio de Janeiro, 1966, p. 259/261.

(46). - Em História e Tradiçōes da cidade de Säo Paulo, dividiu Ernani da Silva Bruno a história paulistana em fases, nas quais, o "burgo de estudantes" corresponderia a 1828/1872 e a Metrópole do Café" a 1872/1918. 
função apenas política e cultural (47), já em 1883 poderia ser considerada a "Metrópole do café", com nítida e acentuada função econômica.

Segundo o Almanaque da Província de São Paulo de Assis Moura, naquele ano a cidade possuia grande número de casas atacadistas: 45 de produtos alimentares e bebidas, alem de 24 destinadas a vestuário, bem como 15 de artigos para construção. O comércio varejista dispunha de 547 casas fornecedoras de alimentos e bebidas, 70 lojas de fazendas, modas e armarinho, 13 vendedoras ou locadoras de móveis, 15 charutarias, para citar aquelas que definiam as necessidades maiores da população ou as suas preferências.

Destacando o vulto das transações comerciais encontravam-se 25 casas comissárias e vários estabelecimentos de crédito, ao todo sete.

A indústria ainda muito incipiente, sem merecer destaque especial, era representada por pequenos estabelecimentos, em geral fabriquetas e simples oficinas e ateliers.

O aumento das construçōes urbanas e as reformas dos prédios já construidos permitiam a existência de 33 empreiteiros de obras, 10 engenheiros e 4 mestres "arquitetos".

Em que pese o seu carater elitista, tambem o setor educacional foi beneficiado pelo progresso da cidade crescendo o número de colégios para 13 , convindo ressaltar, pela característica já diferente de uma mentalidade tradicional,

"o aparecimento de instituições de carater filantrópico-educacional que proporcionavam uma formação profissionalizante, com vistas á criação de mão-de-obra mais qualificada. É o caso do Instituto de Educandos Artífices criado pelo governo provincial e do Instituto d. Ana Rosa, criado pela família Sousa Queiroz que se propunham a amparar meninos orfäos fornecendo-lhes formação profissional" (48).

O número de associações recreativas e beneficentes tambem crescera - em dez anos passara de 8 para 30 e algumas delas, como a Societé Française 14 juillet de Bienfaisance, o Real Club Ginástico Português, a Sociedade Suissa de Beneficência Helvécia, a Societá Ita-

(47). - Diria Zaluar a respeito da São Paulo de 1860: — "Tirem a Academia de São Paulo é esse grande centro morrerá inanimado. Sem lavoura e sem indústria montadas em grande escala a capital da Província, deixando de ser o que é deixará de existir". (Apud Odilon Nogueira de Matos, $A$ cidade de São Paulo..., p. 107).

(48). - Laima Mesgravis, ob. cit. 
liana di Beneficenza Vittorio Emanuelle II, refletiam o aumento e a diversificação da corrente imigratória para São Paulo.

Aliás, seria ela que, solicitada pela expansão cafeeira e conjugando-se com esta e as ferrovias numa influência única, separavel apenas para efeito de análise, viria dar nova feição à cidade, como fator importante de sua urbanização.

De certa forma, a "europeização" notada no Rio de Janeiro a partir da chegada da corte portuguesa no Brasil, ocorre em São Paulo nessa época e com uma feição bem mais cosmopolita.

A influência estrangeira, notadamente a italiana, refletir-se-á no futuro em todos os setores da atividade urbana, fazendo-se muito visivel na arquitetura dos prédios, na importância que adquiriram as atividades musicais, etc. .

O processo de urbanização se reflete na população: os 31.385 habitantes da cidade em 1872, seriam $47.696 \mathrm{em} 1886$ e $64.934 \mathrm{em}$ 1890.

Esse crescimento por sua vez determina a expansão espacial a cidade que até meados do século aproximadamente ocupava quase a mesma área que tivera nos tempos coloniais, expande-se sensivelmente através do loteamento de chácaras e sítios dos arredores, gerando novos bairros.

Os campos do Bexiga transformaram-se no Bairro da Bela Vista; a antiga chácara do Campo Redondo tornou-se o bairro dos Campos Elíseos. A Chácara das Palmeiras que ainda em 1872 possuía grandes plantações de chá deu origem ao bairro de Santa Cecília, bem como da chácara de dona Ana Machado resultaria o atual bairro da Liberdade.

Com essa expansão, realizada sobretudo a partir dos anos 80 , a cidade passa a conhecer as diferenças funcionais, surgindo ao lado do velho centro, os bairros operários e os residenciais finos. Até ali,

"as residências dos homens abastados e da classe média localizavam-se no próprio triângulo, de mistura com as casas de comércio e as pequenas oficinas" (49).

Os operários organizaram-se condicionados pela presença das vias-férreas, instalando-se perto das estações ferroviárias e ao longo das linhas: 120.

(49) , - Odilon Nogueira de Mattos, "A cidade de São Paulo..., p. 
"Estas não acompanham as antigas vias de comunicação, situadas em regra nos altos; instalam-se naquelas baixadas, onde encontram um terreno mais igual e facil" (50).

Foi assim que, em terras pouco saudáveis que ninguem queria, mas a partir de então impulsionadas pelas ferrovias, cresceram os bairros do Brás, da Luz e do Bom Retiro. O primeiro, que em 1872 contava 2.300 moradores, teria em 1886 mais de 6.000 , para lá afluindo os italianos, após essa época, em quantidades crescentes.

Os primeiros bairros residenciais mais finos instalaram-se no topo das colinas para alem do Anhangabaú, destacando-se os Campos Elíseos, durante muitos anos o local preferido da nova aristocracia do café.

Outros bairros residenciais apareceram, com mais modestas pretensões,

"seguindo quase sempre as vias de comunicação que punham São Paulo em contato com o litoral ou o interior":

no rumo do sul, os da Liberdade e Vila Mariana; na direção de Pinheiros o bairro da Consolação; a caminho do litoral, o Cambucí.

Como é natural, as transformaçōes sócio-econômicas provocaram novas e numerosas aspirações que buscavam ser satisfeitas e, quando frustradas, tentavam identificar os entraves à sua realização. Um deles, na opinião de consideravel parcela da opinião pública seria a centralização que caracterizava a administração imperial, responsabilizada como um entrave ao desenvolvimento do país.

O regime monárquico, até então firmemente consolidado, sobrevivera, favorecido pela ausência de conflitos fundamentais entre os grupos dominantes e pelo equilíbrio entre poder político e poder econômico. Contudo, a dinamização acelerada de áreas até então inexpressivas, como era o caso do Oeste paulista, por exemplo, vem colocar em risco os quadros tradicionais, aprofundando as contradiçōes e cindindo os grupos dominantes a propósito de questōes fundamentais como a extinção do regime servil, o tipo de mão-de-obra que deveria substituir o braço escravo, se nacional ou estrangeiro, chegando-se por último ao questionamento do próprio regime político.

(50) . - Caio Prado Júnior, "Nova contribuição para o estudo geográfico da cidade de São Paulo", p. 209, Estudos Brasileiros, ano III, vol. 7, n's 19, 20, 21. Rio de Janeiro, 1941. 
Coincidentemente abalavam-se as bases econômicas das oligarquias manipuladoras do poder, na medida em que a economia açucareira não conseguia superar as crises e declinava a produtividade das propriedades cafeeiras do Vale do Paraiba.

A assincronia entre o poder político e o econômico era vivamente sentida pelos paulistas. Já se mencionou aqui o fato de São Paulo, justamente no período mais dinâmico de sua economia durante o regime monárquico, ter dado apenas 10 ministros em 14 governos que dirigem o país de 1868 a 1889 , quando a Bahia, por exemplo, teria 26 representantes.

No ano de sua queda, 1889, o Império contava com 59 senadores. Destes, apenas três provinham de São Paulo, número equivalente ao do Pará. Enquanto isso, Bahia e Pernambuco davam seis, Rio de Janeiro, cinco, e Minas Gerais, dez.

Na Câmara dos Deputados nove elementos compunham a bancada paulista, ao passo que Pernambuco dispunha de 13, Município da Corte e Rio de Janeiro 12, Minas Gerais 20 e a Bahia, 14.

O mesmo observava-se no Conselho de Estado onde predominavam os representantes principalmente da Bahia, Minas, Rio de Janeiro (51). E ainda que a enumeração seja fastidiosa, não se pode esquecer que

"entre março de 80 (ascenção de 28 de março) e novembro de 89, menos de 10 anos, a presidência do Conselho de Ministros cabe durante mais de 7 anos a políticos da Bahia" (52).

Mesmo na presidência da Província, segundo a norma da época, predominavam os elementos vindos de fora. Dos 71 presidentes que governaram no período monárquico, 43 provinham de outras regióes. Entre 1852 e 1860, por exemplo, apenas um, entre 10 governantes, foi paulista.

Ả vista de tais circunstâncias, fortalecia-se a idéia de que não convinha a São Paulo entrar com capital e trabalho e em contrapartida, receber administradores de outras terras e leis formuladas por gente estranha.

Por outro lado a absorção crescente das províncias pelo poder central não consultava à prosperidade de quem a sentia como um freio que limita a expansão das energias. As queixas e as demonstrações

(51) - Emília Viotti da Costa, "A proclamaçăo da República", Anais do Museu Paulista, tomo XIX, São Paulo, 1965.

(52) . - Sérgio Buarque de Holanda, "Do Império de República", p. 271. 
dessas amarras sucedem-se: argumentava-se lembrando que as grandes distâncias impediam uma administração eficaz e que as diferenças regionais impossibilitavam a uniformidade administrativa pretendida pela centralização.

A lógica dos números era continuamente evidenciada: entre 1875 e 1884 o movimento comercial do porto de Santos mantivera-se, com ligeitas oscilações, na casa dos vinte mil contos. A exportação aumentara sensivelmente: de $25.487: 450 \$ 844$ no exercício de $1875-76$ para 48.580:654\$106 no de 1884-85. A renda da Província era de 25 mil contos de réis em 1887, dos quais, 4 mil, destinados ao orçamento provincial:

- "Quer isto dizer que São Paulo concorre todos os anos com uma parcela superior a 20 mil contos para a manutenção dos pesados encargos da união monárquica",

diria um revoltado paulista (53).

Os confrontos sucediam-se:

- "Só a Alfândega de Santos em três meses compensa toda a despesa que o governo geral faz com os paulistas durante o ano" (54).

Quem quizesse ver seu filho engenheiro ou farmacêutico teria de manda-lo à Corte, já que o ensino superior não entrava na competência das Assembléias Legislativas Provinciais.

Vozes levantavam-se na Assembléia contra tal estado de coisas. Dramaticamente bradaria o terceiro Martim Francisco, em 1884:

- "Negam-nos tudo: Quando queremos progredir ostentamse contra nós os anéis da engrenagem centralizadora; ocupam nossos empregos com gente estranha à nossa vida, aos nossos interesses, e aos nossos meios de ação..." (55).

Ả raiz de tal revolta contra a centralização, nota-se outra, mais relevante, contra a continuação do recrutamento, justamente nas áreas empobrecidas, dos elementos que manipulavam o poder e que acentuavam a crescente assincronia entre poder político e o econômico. E

(53) . - Alberto Salles, ob. cit., p. 185.

(54). - Idem, p. 186/187. 1934, p. 26.

(55) . - Apud Tácito de Almeida, O movimento de 1887, Sāo Paulo, 
o que se depreende das palavras de outro paulista da época, Joaquim Fernandes de Barros:

— "Tendo o Norte em outros tempos sabido morrer pela República pelo bem que mereceu da Pátria, porem estando hoje por muitas circunstâncias inválido e estropiado, de maneira a não poder acompanhar o passo largo e seguro do Sul votamos-lhe todas as honras da História e o aposentamos com o ordenado por inteiro, pago de uma só vez" (56).

\section{Comentava-se ser}

"raro o dia em que não se ouve uma queixa amargamente articulada contra o governo central" "pela maneira pouco airosa"

para os brios provincianos com que dirigia e zelava dos paulistas (57).

Tal evidência,

"de cuja gravidade para o regime os estadistas da monarquia não se aperceberam senão lentamente, e quando acordaram já era tarde, dava em tais áreas uma nova dimensão para a idéia liberal que, associada ou não, ao republicanismo, constituía mais um desafio sério à estabilidade do sistema imperial" (58).

Este último sofreria o primeiro impacto público desagregador com o manifesto republicano de 1870 e com a criação do partido republicano do Rio de Janeiro, a que logo se seguiu a criação do núcleo de São Paulo e outros, ampliando-se a influência da idéia através dos clubes republicanos e dos jornais que rapidamente proliferam.

Em análise a que procedeu sobre a distribuição đos clubes e jornais republicanos existentes no país às vésperas de 1889 , revelaria Oliveira Viana que $73 \%$ dos jornais e $89 \%$ dos clubes concentravam-se no Sul, especialmente em São Paulo, Rio de Janeiro e Rio Grande do Sul (59).

Essa concentração no Sul ainda uma vez evidenciava o desejo das áreas mais dinâmicas de imprimir à vida econômica e política do país as suas próprias diretrizes, uma vez que, a essa altura, regime monárquico e centralização pareciam indissoluvelmente ligados.

(56) . - J. F. de Barros, A Pátria Paulista, Sāo Paulo, 1887, p. 49.

(57). - Alberto Salles, ob. cit., p. 107.

(58) . - Sérgio Buarque de Holanda, "Do Império à República", p ..275.

(59). - Cf. Emília Viotti da Costa, "A proclamação da República". 
Não seria portanto de estranhar que em São Paulo o partido republicano se tornasse

$$
\begin{aligned}
& \text { "muito antes e muito mais do que nas outras províncias uma } \\
& \text { força poderosa, coesa, organizada..." }(60) \text {. }
\end{aligned}
$$

Mas seria normalmente estranhavel a circunstância do partido republicano contar de pronto, como aconteceu em São Paulo, com apreciavel número de adeptos provenientes do meio rural, se se pensar na norma, em geral observada de que as zonas rurais são mais rotineiras, conservadoras, ao passo que as urbanas, suscetíveis de aderir mais rapidamente às inovaçōes.

Entre os 133 participantes da Convenção Republicana de Itu, 76 declararam-se lavradores. Tambem se constituia de fazendeiros, especialmente de Campinas e Itu, a maioria dos subscritores do jornal $\boldsymbol{A}$ Provincia de São Paulo, orgão que se tornaria o mais importante do Partido Republicano Paulista.

Analisando o fenômeno, uma historiadora lembraria que esses elementos rurais pertenciam quase exclusivamente ao Oeste paulista, notando-se a ausência dos fazendeiros do Vale do Paraiba em geral nos quadros do Partido Republicano (61). A explicação se deveria a dois fatores: o da necessidade do ideal republicano como instrumento para chegar ao poder e controla-lo de maneira mais eficaz e às características diversas dos fazendeiros do Oeste, se comparados aos de outras áreas. Na verdade esses fatores imbricam-se em outros dois: a prosperidade daquelas zonas face à expansão das lavouras e à composição social dessa frente pioneira, menos sedimentada e assim mais permeavel e sujeita a influências inovadoras.

Embora não necessariamente, à idéia de república aliar-se-ia a de federação, como forma de escape à engrenagem centralizadora. Não era o federalismo uma idéia nova, tendo já sido invocada em diversas ocasiões como expressão nāo só das diferenças regionais mas da longa tradição descentralizadora que já caracterizara a vida do Brasil quando colônia. Figurava tambem na época que abordamos, entre as reinvindicaçōes teóricas do partido liberal, mas ganharia grande impulso e numerosos adeptos com o crescimento da idéia republicana.

Sintomaticamente reza o Manifesto de 1870:

— "O regime de federação baseado na independência recíproca das províncias, elevando-ds à categoria de Estados próprios

279.

(60). - Sérgio Buarque de Holanda, "Do Império à República, p.

(61). - Emilia Viotti da Costa, "A proclamaçāo da República". 
unicamente ligados pelo vínculo da nacionalidade e da solidariedade dos grandes interesses de representação e defesa exterior, é aquele que adotamos".

Em São Paulo o descontentamento causado pelo crescente desequilíbrio entre o poder político e o econômico, e a irritação que a atividade centralizadora provocava traduziam-se no crescimento contínuo da idéia federal e republicana, a ponto da primeira, exacerbando-se, confundir-se com separatismo.

Tal extremismo, revelando o grau de tensão existente no período final do Império, seria expresso por Ferreira de Menezes em 1877, para quem a idéia de separação sorria aos paulistas dia e noite:

- "Todos os anos somam os paulistas o que receberam do governo geral e comparam com o que deram ao mesmo; ora, como já dão mais do que recebem, e sendo como são homens positivos, poetas práticos, já murmuram: por que não havemos de ser independentes" (62).

Dois anos depois, Martim Francisco III, lamentaria na Assembléia Provincial:

- "tanta riqueza malbaratada, uma província que só por si poderia constituir um Estado e que em menos de dez anos de paz e de trabalho seria a primeira potência da América do Sul" (63).

Os "murmúrios" separatistas transmudar-se-iam no que Tácito de Almeida chamou "o movimento de 1887". Nesse ano, a 11 de fevereiro, pelas colunas do Diário Popular, Francisco Eugênio Pacheco e Silva

"levanta a flâmula do separatismo em termos de combate, como aspiração máxima dos paulistas", argumentando: - "Do modo pelo qual as coisas correm, só a absoluta falta de patriotismo e de coragem cívica pode conservar um filho ou habitante da Província de São Paulo indiferente à questão da separação" (64).

No dia seguinte, 12 de fevereiro de 1887, Joaquim Fernando de Barros secundava a idéia através das colunas de A Província de São Paulo. Sob a forma de cartas publicadas de fevereiro a abril, logo

(62). - Apud Tácito de Almeida, ob. cit., p. 17.

(63). - Idem ibidem, p. 26.

(64). - Idem Ibidem, p. 19. 
reunidas em folheto de distribuição gratuita, pregaria o surgimento da Pátria paulista, analisando os meios que mais facilmente poderiam levar ao êxito de tal aspiração.

Tambem Alberto Sales, irmão de Campos Salles, dedicaria suas forças à propaganda separatista, em livro impresso em Campinas naquele mesmo ano sob o significativo título de $A$ Pátria paulista.

Sob a influência de Spencer, para ele,

"a encanarção mais poderosa do pensamento moderno", considera o separatismo a "consequência fatal de um estado de amadurecimento, de uma força econômica e social muito viva, represada em longos anos de trabalhos e padecimentos, consolidada pelo espírito de iniciativa, honestidade e teimosia dos paulistas". Essa providência deveiia abrir caminho à federaçāo, sendo "impossível sustentar-se com seriedade que a federação é que deve preceder ao separatismo".

Menos complacente seria Martim Francisco advogando uma separação sem compromissos com outras partes de um Império que se esboroava como velho edifício. Espírito mordaz, irônico, revolvia estatísticas que espelhavam a contribuição paulista ao Império concluindo acremente:

- "Ando desconfiado de que meus co-provincianos descendem em linha reta de Jesus Cristo: este pagou todas as culpas do gênero humano; aqueles pagam todos os desfalques do norte e todas as consequências da incapacidade dos ministros" (65).

O movimento alcançaria ressonância alastrando-se a propaganda nas sessōes pagas dos jomais. Em conferência proferida no Clube republicano de Campinas a 13 de maio de 1887 , o paranaense Ubaldino do Amaral advoga a idéia de separação antecedendo federação. Assim tambem pensaria o pernambucano Saldanha Marinho (66). A favor ainda manifestar-se-ia Campos Salles, Carlos Garcia, entre os mais conhecidos.

(65). - Apud Tácito de Almeida, ob. cit., p. 27.

(66) .. - Em muitos desses políticos nota-se a marca do positivismo, mas "ao contrário do que se dá com os republicanos rio-grandenses não é tanto o comtismo que os atrai, como uma concepção que tem raizes em Spencer, por eles frequentemente citados; e o estereótipo que constroem para o paulista trai uma inspiração vizinha do darwinismo social" (Sérgio Buarque de Holanda, "Do Império à República", p. 276). 
Não seria por acaso que tais idéias seriam veiculadas e encampadas por elementos do Oeste em sua quase totalidade.

Em fins de maio de 1887 reuniu-se em São Paulo o Congresso do Partido Republicano. Uma moção separatista é apresentada por delegados de alguns municípios, mas, a despeito das numerosas adesões $\mathrm{e}$ de poucas manifestações reticentes, não prevalece a idéia radical. Júlio de Mesquita é um dos que a ela se opõe, julgando-a inconveniente e contraproducente para o partido.

A solução republicana federativa aparece como a mais indicada, atendendo os interesses das zonas agrícolas mais adiantadas sem por em risco a unidade nacional.

E com ela que São Paulo permanece em 15 de novembro de 1889, quando, com a instalação da República, se inicia um novo império: o dos fazendeiros.

\section{I}

Com efeito, o regime republicano veio propiciar aos paulistas o poder que lhes fora negado no período monárquico. Não mais teriam de pedir, agora,

"à alta tutela majestática" a solução de problemas "que a política imperial adiava indefinidamente" (67).

Outorgando autonomia administrativa e amplos direitos aos Estados a república federativa resultou na prática em verdadeira soberania, o que para São Paulo, onde já se fazia sentir sensivelmente o impulso da iniciativa privada, foi de grande valia, facilitando-lhe a expansão econômica e permitindo-lhe agir desembaraçadamente no fomento da riqueza pública. Através desse regime puderam os paulistas ampliar cs seus meios de ação tendo em vista a expansão e defesa do produto que era o sustentáculo econômico da regiâa e que lhe conferiria progressivamente a hegemonia e liderança. Nesse sentido poder-se-ia notar, no período que se convencionou chamar de República Velha, que a história paulista se caracterizou pela sincronia entre o poder político e o econômico. Seria e época de domínio do setor agrário exportader, favorecido pelo incremento das lavouras cafeeiras.

Realmente a facilidade de transportes no escoamento da produçāo, a mão-de-obra livre, a forte inflação de circulação monetária nos primeiros tempos do regime republicano, seriam fatores da expansão sem peias da cafeicultura.

(67). - João Pedro da Veiga Filho, Estudo econômico e financeiro sobre o Estado de São Paulo, São Paulo, 1896, p. 43 e 81 . 
Há uma febre de plantações no período imediatamente posterior à proclamação da República $\mathrm{e}$, para termos de comparação, lembraríamos que, enquanto a safra de 1886-1887 fora de 1.672.000 sacas de 60 quilos, a de 1900-1901 seria de 7.988.000, aumento, portanto de $377,8 \%$ em pouco mais de um decênio (68).

De 1890 a 1900 o número de cafeeiros mais que duplica, passando de 220 a 520 milhões (69).

Em 1902 a safra alcançaria mais de 8 milhões de sacas, passando São Paulo a fornecer $65 \%$ do café brasileiro quando poucos anos antes, ou seja em 1888, fornecia $40 \%$ do total da produção do Brasil (70).

Contudo, a euforia da marcha para o oeste, da penetração contínua, da demanda crescente e consequente alta de preços cessaria logo: - se a larga expansão da produção cafeeira trouxe ao país e a São Paulo em particular riqueza e progresso,

\footnotetext{
"não lhe faltou muito cedo a contrapartida da supe produção que acompanhará a vida da economia cafeeira do Brasil desde poucos anos depois do início do seu grande ciclo de crescimento até os dias de hoje" (71).
}

Esse o aspecto mais importante da história do café, de tão amplos efeitos na economia do país e que tem suas raizes no depender tradicionalmente a nação de um único produto agrícola de exportação.

Até 1896 o consumo mundial absorveria a produção paulista, o que já não acontece daí pàra a frente. Aparecem então as sobras que, nos anos seguintes, se acharão às origens da crise. Até então, ou melhor, de 1887 a 1896 , o café alcança altos preços, podendo situar-se os anos de 1893 a 1894 como aqueles em que maiores preços alcançou: em média $14 \$ 770$ por 10 quilos tipo Santos. O resultado é que, no quinquênio seguinte a produção será em média $100 \%$ maior que a do anterior. Rompe-se o equilíbrio entre oferta e procura e os preços caem. Em 1900-1901 estavam a $6 \$ 160$ por 10 quilos chegando em 1905-1906 a $4 \$ 000$ em média (72). A administração se alarma, estabelecendo em 1902 um imposto sobre novas plantações e chegando ao ponto de, nesse mesmo ano, reduzir os vencimentos de todo o funcionalismo público, e propondo-se restabelece-los

(68). - Camargo, ob. cit., I, p. 189. 1956, p. 235

(69) - Caio Prado Júnior, História econômica do Brasil, São Paulo,

(70). - Roberto Simonsen, $o b$. cit., p. 213.

(71). - Caio Prado Júnior, História econômica, p. 234.

(72). - Roberto Simonsen, ob. cit., p. 213. 
"à proporção que se iam desafogando as condições financeiras do Estado" (73).

Em 1906-1907 a safra atingia 16 milhōes e a baixa de preços vinda dos anos anteriores perdurava. A especulação comercial jogava largamente com a situação aproveitando-se da necessidade do produtor de ceder suas colheitas para atender aos encargos da produção, o que se fazia em favor dos grandes estabelecimentos financeiros e bancos internacionais que auferiam os lucros em detrimento do produtor.

A necessidade de se defender contra tal estado de coisas levará os produtores a pleitear medidas suscetíveis de sustentar e estabilizar os cursos do café. Surge o acordo conhecido pelo nome de Convênio de Taubaté, segundo o qual, os maiores estados cafeeiros, São Paulo, Minas Gerais e Rio de Janeiro, retirariam da circulação a maior parte das safras, ressarcindo os fazendeiros e mantendo altos os preços, o que diminuiria os riscos das colheitas excepcionais. Para essa intervenção lançar-se-ia mão de empréstimos estrangeiros.

$\mathrm{Na}$ verdade, caberia a São Paulo, o maior interessado, e então sob a presidência de Jorge Tibiriçá, a iniciativa dos empréstimos e do controle da produção, por ser o único.em condições de arcar com tais responsabilidades que no entanto beneficiariam tambem os demais estados produtores.

"Paulisticamente" diria a respeito Basílio de Maganlhães: "ante essa horrorosa conjuntu:a os enérgicos administradores de São Paulo não protelaram o emprego de imediatas e decisivas providências: arrendaram a Sorocabana, havia pouco adquirida, levantaram um empréstimo de 3 milhões de libras e logo depois out:o de 15 milhöes e entrando na praça de Santos apercebidos da única arma que hoje em dia e por toda parte vence - o dinheiro - retiraram do mercado de exportação 8.500 .000 sacas de café, armazenando-as nos principais portos de consumo, aquém e além Atlântico" (74).

Encontrara-se nesse expediente oportunista a fórmula do êxito. As novas plantações continuam, tanto que no decênio de 1901 a 1910 os cafeeiros paulistas aumentarão de 150 milhões (75) .

No ano de 1911-1912 a exportação de café pelo porto de Santos alcançará o nivel de 9.143 .685 sacas de 60 quilos no valor de 435.605 contos de réis (76).

\footnotetext{
(73). - Basílio de Magalhães, ob. cit., p. 49.

(74). - Idem, ibidem, p. 42.

(75). - Caio Prado Júnior, História econômica, p. 235.

(76). - Basílio de Maganlhães, ob. cit., p. 24/25.
} 
Mas a primeira guerra mundial provocaria outra crise, de âmbito menor, é verdade, com a retração dos mercados consumidores e consequente redução das exportações, desorganizando o comércio. Pensam os paulistas em nova valorização, agora dificultada pelos obstaculos que a guerra opõe aos empréstimos externos. O governo federal compra então os estoques, caracterizando-se essa segunda valorização, a de 1915-1917, pelo fato de situar-se agora o mecanismo de controle do produto básico de São Paulo fora do âmbito estadual. Tal intervenção bem como a geada de 1918 que devastaria os cafezais paulistas concorrem para o restabelecimento do equilíbrio.

O fim da guerra determina a reabertura dos portos até então fechados e o aumento do consumo, provocador da alta dos preços que, se em 1914-1915 oscilavam em torno de 500 réis, chegam a alcançar $4 \$ 000$ o quilo em 1924-25.

Recomeça assim nessa década de 20 a expansão da lavoura. Novos talhões são plantados,

\footnotetext{
"dentro dos mesmos métodos anteriores, apenas dife-indo no processo de penetração, agora muito mais rápido e avassalador" (77).
}

E a época em que se atinge mais profundamente a Noroeste, a Araraquara, a Alta Paulista e a Alta Sorocabana.

Entre 1918 e 1924 o número de cafeeiros paulistas passará de 828 para 949 milhöes (78) e novamente o fantasma da superprodução assoberbará os cafeicultores, dando margem à 3a. valorização, de 1921-1922. Provocaria esta um impacto maior: o governo federal faz um empréstimo com Rotschild, a juros altos, e compra os estoques; o produto e a venda, contudo, ficam sob o controle de uma firma anglo-americana, a Brazilian Warrant $\mathrm{Co}$, escapando o café pela primeira vez totalmente das mãos dos produtores ou do Governo (79) .

Com o fito de retomar o controle de seu produto maior, São Paulo fundaria em 1924 o Instituto Paulista de Defesa Permanente do Café, que transformado dois anos depois em Instituto do Café do Estado de São Paulo, controlava inteiramente o comércio exportador, regulando as entregas ao mercado de molde a manter o equilíbrio entre oferta e procura.

(77) - - J. R. Araujo Filho, "O café, riqueza paulista", Boletim Paulista de Geografia, 23, São Paulo, 1956, p. 105.

(78). - Caio Prado Júnior, História econômica, p. 240.

(79). - Edgar Carone, Oligarquias e classes sociais na Segunda República (1930/1937), São Paulo, 1974, p. 18. 
A produção continua a aumentar, atingindo em 1927 a quantidade de 26 milhões de sacas que traziam em seu bojo os prenúncios de uma crise de superprodução. Nesse mesmo ano possuía o Brasil 2 bilhões e meio de cafeeiros dos quais 1.333.850.000 situavam-se em São Paulo (80).

A expansão tinha sido feita à custa de créditos que endividaram pesadamente a lavoura cafeeira. A concorrência externa aumentara através de paises produtores que tambem haviam alargado a sua produção. Manobras altistas levam ao acúmulo de estoques ao passo que o consumo mundial era inferior à produção brasileira .

Tal a situação quando se dá o crack da Bolsa de Nova Iorque. O fenômeno repercute intensamente determinando o caos e o pânico nos meios cafeeiros. A crise que se segue em decorrência interrompe definitivamente a expansão, liquidando o império dos fazendeiros. Embora continuasse a ser um produto agrícola de cabal importância já não representaria o café, daí para frente, o valor máximo na economia paulista.

Contudo, enquanto o foi, favoreceu um processo auto-estimulante e cumulativo que envolveu interesses mercantis, financeiros e até manufatureiros, num vasto e poderoso complexo econômico.

Convem lembrar que, concomitantemente e contribuindo para tanto, continuaria a imigraçāo, especialmente a estrangeira, a ampliar-se no período, obedecendo todavia a fases de retração e expansão, em consonância com as vicissitudes da lavoura. Assim é que no período dẻ grande expansão da agricultura ocorrido entre 1885 e 1896 observa-se tambem um amplo movimento imigratório. O ano de 1891 acolheria 108.688 estrangeiros em São Paulo mas o momento máximo seria em 1895, quando, desembarcam 140.000 imigrantes. Nesse ano, dispendia a administração cerca de $14,5 \%$ de suas despesas orçamentárias com os serviços imigratórios.

No período da crise surgiria a retração. É possivel que os salários não se tenham reduzido acentuadamente como quer Holloway (81) mas, a queda do câmbio desanimava os imigrantes, desejosos de remeter dinheiro à terra de origem. Alem disso o governo federal suspenderia então quase totalmente as subvenções à imigração e o acúmulo de estoques desestimularia, com certeza, os fazendeiros a interessar-se por novos contingentes.

Oscilante até 1910 a corrente imigratória cresce novamente a partir daí. Em 1911 entraram 64.990 estrangeiros, dos quais, 43.532

(80). - Camargo, ob. cit., I, p. 230.

(81). - Thomas Holloway, ob. cit., p. 159. 
deslocaram-se espontaneamente. Em 1912, viriam 101.947 (82) mas é em 1913 que a corrente imigratória atingirá de novo um máximo, quando aqui chegarem 116.640 estrangeiros: último grande contigente recebido por São Paulo (83).

Assim, pode-se apontar como característica saliente do período que vai de 1885 a 1915 uma grande expansão imigratória que decresce nos anos seguintes em virtude das crises provocadas pela primeira guerra.

O surto cafeeiro da década de 20 determina o recrudescimento da corrente imigratória: em 1926 chegam a São Paulo 76.796 estrangeiros. Mas os rumores de crise fazem decrescer o movimento que arrefece para quase anular-se com o rompimento da Segunda Guerra Mundial.

Naquela década já não se destacam no influxo os mediterrâneos que haviam predominado no início. Um quadro organizado pelo Departamento de Imigração e Colonização sobre o total de imigrantes distribuídos por nacionalidades e vindos para São Paulo, entre 1870 e 1951 (84), mostra que a década de 80 foi aquela em que a proporção de italianos alcançou a máxima porcentagem em relação ao total de estrangeiros: de 1880 a $1889,183.505$ imigrantes, dos quais 144.654 oriundi, numa proporçāo de $78,83 \%$

Os dez anos seguintes acusam uma quantidade maior em números absolutos, 340.243 , para uma porcentagem de $58,54 \%$, já que o número total de estrangeiros foi de 734.985. Entre 1900 e 1909 chegaram 364.834 imigrantes, dos quais 174.634 provenientes da Itália $(47,48 \%)$.

De 1910 a 1919 a porcentagem foi de $23,7 \%$ e na década de 20 , de $15,35 \%$.

A soma das quantidades apontadas mostra que no período da Primeira República São Paulo recebeu 2.033.654 estrangeiros, dos quais, 1/4 aproximadamente, eram italianos: 695.489.

Esse número se deve mais às duas primeiras décadas do século: já entre 1925 e 1929 , por exemplo, do total de estrangeiros que entraram no Brasil muitos provinham da Europa Oriental, e pertenciam a minorias dissidentes criadas pelo Tratado de Versalhes. E agora tambem se fazia notar em quantidade razoavel, a mão-de-obra japo-

(82) . - Basílio de Magalhães, ob. cit., p. 76.

(83). - Camargo, ob. cit., I, p. 229.

(84). - Apud Arlinda Rocha Nogueira, A imigraçäo japonesa para a lavoura cafeeira paulista (1908/1922), São Paulo, 1973, p. 41. 
nesa, cuja imigração iniciada em 1908 com o inexpressivo número de 825 elementos, ascende a 27.114 entre 1910 e 1919 para chegar a 57.164 durante os anos vinte, correspondendo a $11,73 \%$ da imigração estrangeira do período, e assumindo papel mais relevante em fases subsequentes $(85)$.

E a partir dos anos vinte tambem que, o movimento de migração interna dos estados do nordeste toma impulso em direção a São Paulo, chegando em 1928 a ultrapassar a imigração estrangeira para suplanta-la completamente a partir de 1934 .

Obedecendo a intensidade variavel o afluxo de elementos, nacionais ou estrangeiros, resultante da lavoura cafeeira que assim se comporta como fator de povoamento aumentaria sobremaneira a população do Estado.

Entre 1886 e 1900 esse aumento ocorreu na base de $86,6 \%$; de 1900 a 1920 a população dobrou e nos vinte anos subsequentes cresceu na ordem de $56,4 \%$ (86).

Os dados compilados por Lefevre (87) mostram como em 1890 São Paulo era o terceiro Estado do Brasil em população, com 1.384.753 habitantes. Minas detinha o primeiro lugar com 3.184.099. No ano de 1930 esta última continuava ainda à frente com 7.035.025 habitantes mas São Paulo, com 6.100.705 habitantes, já era o segundo Estado, diminuindo largamente a diferença que o separava anteriormente de outros Estados e que se anularia de vez pouco tempo depois. Se em Minas dobrara a população naqueles 40 anos, em São Paulo crescera quatro vezes e meia no mesmo período. Convem notar ainda que a diferença acusada em números absolutos desfazia-se na comparação da densidade populacional. Enquanto Minas em 1930 tinha 11,9 habitantes por $\mathrm{km}^{2}$, São Paulo tinha 24,6.

Quanto à sua composição a população paulista era representada por $1 / 5$ de estrangeiros por volta de 1920 , dos quais, metade, constituidos de italianos, proporção que se irá reduzindo nas décadas seguintes.

O crescimento populacional concomitante com a marcha do café significaria tambem nova proliferação de municípios, cuja criação, a exemplo do movimento imigratório, acompanharia estreitamente as vicissitudes da lavoura. Em Pionniers et planteurs, Pierre Mombeig exemplifica-o largamente, lembrando que nos últimos anos do século

(85). - Apud Arlinda Rocha Nogueira, ob. cit., p. 41.

(86). - Camargo, ob. cit., I, p. 264.

(87). - Eugênio Lefevre, A administração do Estado de São Paulo na Repüblica Velha, São Paulo, 1937, p. 441/442. 
XIX se criaram 41 novos municípios na sua grande maioria em regiões desbravadas naquele momento; como reflexo da crise anulou-se a tendência entre 1900 e 19i0, para ressurgir novamente entre 1910 e 1919 com 32 novos núcleos a que se somaram outros 52 entre 1919 e 1929 , naquele após-guerra que traria situação aparentemente próspera e análoga à do fim do século precedente.

Nessa expansão, a despeito de uma lavoura com base no latifúndio, as propriedades agrícolas multiplicaram-se como se pode depreender dos dados oferecidos pelos recenseamentos.

Existiam em todo o Estado de São Paulo 56.931 propriedades rurais das quais 8.432 pertenciam a estrangeiros numa proporção de $15,7 \%$. Em 1920 o Censo relaciona 80.921 , sendo que 22.054 possuidas por não-brasileiros, índice de $27,3 \%$, que se eleva a $35,5 \%$ em 1934 para posteriormente registrar uma tendência à queda, numa proporção de $27,9 \%$ em 1940 .

Entre os estrangeiros proprietários predominavam os italianos, na porcentagem de $61,4 \%$ do total de estrangeiros em 1905 e de $44,4 \%$ em 1920, reduzida posteriormente ao período em análise, em favor de outros imigrantes entre os quais sobressaem os japoneses (88).

Poder-se-ia pensar que a maior quantidade de proprietários estaria explicando o declínio do latifúndio mas na verdade subsistia a estrutura, explicando-se o crescimento do número de propriedades pelo avanço contínuo do café, em seu abandono das terras esgotadas.

O paralelismo já notado entre expansão das lavouras e imigração estrangeira, povoamento, criação de municípios, observar-se-ia ainda na extensão das ferrovias, que se orientam no período em função da marcha do café: a penetração do hinterland já iniciada a partir de 1870 pela Paulista, Mogiana, Sorocabana, Ituana e Bragantina continuaria com maior vigor até o final do século. São Paulo contava em $1900 \mathrm{com} 3.468 \mathrm{~km}$ de vias férreas, um incremento de $87,3 \% \mathrm{em}$ relação a $1886(89)$.

Continuando a marcha para o oeste, a rede ferroviária paulista era de $6.595 \mathrm{~km}$ em 1920 , tendo crescido $90,2 \%$ nesse período.

De $1920 \mathrm{em}$ diante, todavia, o ritmo de crescimento diminui e segundo a diretriz que alcança os nossos dias,

(88) . - Camargo, ob. cit., I, p. 234/235.

(89). - Idem, I, p. 217. 
"a estrada de rodagem passou a ser concorrente e mesmo substituta da ferrovia, inclusive para grandes distâncias, em lugar de se entrosar com esta, propiciando um aproveitamento máximo do sistema de transportes do país" (90).

Em 10 de janeiro de 1932 possuia o Brasil $121.000 \mathrm{~km}$ dé estradas de rodagem em números redondos, cabendo a São Paulo cerca da quarta parte (91) .

Definindo-se pela monocultura (92) o café no entanto se faria em estímulo para o importantíssimo setor que projetaria São Paulo e acentuaria de longe a sua liderança econômica: o da indústria manufatureira.

A explicaçāo é habilmente sintetizada por Caio Prado Júnior ao mostrar que os efeitos da riqueza produzida pelo café se irradiaram e difundiram,

\begin{abstract}
"embora amortecidos mas assim mesmo bastante significativos, sobretudo quando confrontados com os níveis de épocas anteriores - por outros setores da vida brasileira. Isto particularmente em consequência do fato que o enriquecimento direta ou indiretamente proporcionado pela produção e exportação do café, determina nos principais centros de negócio, e em São Prulo em particular, uma ampliação geral da demanda e do consumo de bens econômicos e pois um crescente mercado local que abre oportunidades para outros negócios e atividades" (93).
\end{abstract}

Dentre essas atividades, a industrial iniciaria sua marcha ascensional não em oposição mas em resultado da riqueza agrícola. A esta coube motivar, como já foi dito, o crescimento de mercado consumidor, proporcionando um capital excedente à procura de investimentos fora da atividade agrária e aguçando o espírito empresarial que já se vinha apurando na empresa cafeeira: inexpressiva em São Paulo no período monárquico, razoavelmente fortalecida durante a Primeira República, a industrial intensifica-se em progressão geométrica a partir de 1930 .

(90). - Odilon Nogueira de Matos, Café e ferrovias, p. 130.

(91). - Eugênio Lefevre, ob. cit., p. 433.

(92). - Calcula-se que o valor da exportação de café pelo porto de Santos nos primeiros vinte e sete anos do presente. século ascendeu a um total maior que 17 milhöes de contos de réis, enquanto os demais produtos em igual período figuraram com o valor inferior ao de um ano apenas da exportação de café (Cf. Odilon Nogueira de Matos, Café e ferrovias, p. 111).

(93). - Caio Prado Júnior, História e desenvolvimento (A contribuição da historiografia para a teoria e prática do desenvolvimento brasileiro), São Paulo, 1968, p. 99. 
Uma análise mais detalhada mostra como o café criou as mencionadas condições favorecedoras do crescimento industrial: capitalização, por exemplo, advinda com a economia monetária, o requisito mais elementar de um sistema industrial.

O volume de circulação monetária e o crédito bancário ampliaram-se com o encontro, pelos lavradores, de um mercado que pagava em dinheiro o produto cuja demanda crescia continuamente. $\mathrm{O}$ aumento da mão-de-obra livre e assalariada difundiu a economia monetária na massa da população e mais: o recebimento de salários monetários pelos imigrantes obrigava-os a prover-se nos armazens das fazendas, outra fonte de lucros para os cafeicultores. Representavam ainda esses adventícios vultosos contribuição ao capital disponivel para empreendimentos industriais, mercê das economias que acumulavam.

A série de atividades econômicas geradas pelo café, como a rede de transportes ferroviários e os investimentos em energia elétrica, por exemplo, favoreceriam ainda a industrialização. Foram numerosas as companhias organizadas pelos fazendeiros-empresários com o fito de fornecer energia elétrica. Nesse setor, contudo, bem logo começaria a penetrar o capital estrangeiro, desejoso de lucros que, pelo menos indiretamente, tambem se funđamentavam no café. A Companhia Ãgua e Luz do Estado de São Paulo que forneceu iluminação elétrica à cidade de São Paulo em 1891 foi incorporada em 1899 pela São Paulo Tramway, Light and Power Company Ltda, de Toronto, com um capital inicial de 10 milhões de dólares. Essa subsidiária da Brazilian Traction, Light and Power Company gradativamente absorveu outras companhias locais de energia elétrica, telefone e gás, passando a fornecer energia para as nascentes indústrias e para os serviços de utilidade pública.

O café estimularia tambem a fabricação de máquinas de beneficiamento do produto, dando lugar ainda à primeira e grande indústria textil moderna, a da fiação e tecelagem da juta, empregada na sacaria que acondicionava o café para exportação. Não seria por acaso que o Barão de Piracicaba, fazendeiro do Oeste, juntamente com seu filho Diogo Antônio de Barros, fundaria justamente uma fábrica de fiação e tecelagem, a primeira da Capital. O estabelecimento começou a funcionar em 1872, com 30 teares e 60 operários (94).

Em 1881 registravam-se em São Paulo nove fábricas de fiação e tecelagem com 336 teares e 3.100 fusos produzindo 1.970 .000 metros de pano e 240 mil quilos de fios (95).

(94). - Rjchard Morse, ob. cit., p. 236.

(95). - Roberto Simonsen, ob. cit., p. 15. 
Em 1885 haveria 13 fiações de algodão e uma de lã, pelo menos 4 fundições, algumas serrarias e uma fábrica de fósforos.

No ano de 1901 apontava-se 170 fábricas, entre as quais distinguiam-se 17 fiações e 7 fundições. Cinquenta desses estabelecimentos empregavam mais de 100 operários (96).

Contudo, no início desse surto industrial que já se anunciava durante o Império, a maioria das indústrias concentrava-se no Município Neutro e no Estado do Rio de Janeiro,

"porque o Vale do Paraiba vanguardeava então a evolução ecorômica do país. Por ocasião da implantação da República mais da metade das atividades industriais do país concentrava-se naquela região" (97).

Em 1907 o Centro Industrial do Brasil organizou um recenseamento que indicou 3.250 estabelecimento industriais no país. Mantinha então a primazia o Distrito Federal com $30 \%$ da produção, $24 \%$ do operariado e $20 \%$ do número total de estabelecimentos. São Paulo detinha então $16 \%$ da produção industrial (98).

A partir de 1910 alcançaria a importância maior no quadro da produção industrial do país. Dos 17 cotonifícios de 1901, passa-se à 41 por volta de 1915 , com um número quatro vezes maior de operários. Algumas dessas fábricas estavam equipadas para tecer lã, algodão e juta ou para serviços de estamparia e de malharia destinadas à produção de meias. O valor da produção industrial paulista que era em 1905 de 110 mil contos de réis, eleva-se em 1910 a 189 mil para ascender a $274 \mathrm{mil} \mathrm{em} 1915$ (99).

De 1900 a 1920 o parque industrial paulista expandiu-se rapidamente, à taxa de crescimento anual de $8 \%$ aproximadamente (100), subindo o valor da produção industrial nesse último ano a 1.073 .000 contos. Havia então mais de quatro mil estabelecimentos industriais que empregavam 84 mil operários (101).

Analisando o fenômeno da industriazação em São Paulo, que considera uma singularidade no mundo subdesenvolvido, Warren Dean atribui importância primordial às decisões de nivel empresarial, que

(96). - Warren Dean, ob. cit., p. 19.

(97). - Roberto Simonsen, ob. cit., p. 20.

(98). - Idem, ibidem, p. 17.

(99). - Warren Dean, ob. cit., p. 92.

(100). - Warren Dean, ob. cit., p. 117.

(101). - Aziz Simão, Sindicato e Estado, São Paulo, 1966, p. 14. 
teriam funcionado como fator decisivo para o êxito do processo. Contrariando a idéia por muitos aceita de uma oposição entre setor importador e setor industrial assinala que

"os negócios de importaçăo não constituiam obstáculo ao desenvolvimento da indústria. Pelo contrário, foram claramente a origem de um seto: industrial que cresceu a par das empresas agro-industriais dos fazendeiros" (102).

Por várias circunstâncias, os importadores se envolveram na criação da empresa industrial, possuiam acesso ao crédito, conhecimento do mercado e canais para distribuição do produto acabado.

Continuando em sua argumentação lembra que interessava aos importadores, à medida em que os padrões de consumo aumentam, a conversão de suas agências de venda em fábricas autorizadas. Alem disso o fabricante nacional distribuia seus produtos através do importador e não de atacadistas.

Dessa forma, tendiam os importadores paulistas a perder sua identidade como tal, transmudando-se em fabricantes, o que transformaria o comércio de importação em matriz econômica da industrialização paulista .

Buscando comprovação para suas afirmações assinala que, das 13 fiações de algodão erguidas em São Paulo antes do início do século, 11 eram controladas, por volta de 1917, por firmas importadoras ou por empresários que haviam começado como importadores. No correr do mesmo período teriam sido criadas mais 21 fiações, 16 das quais achar-se-iam sob o controle de importadores (103).

Alem disso, em sua maioria, os grandes empresários do período possuiam experiência de importação. Francisco Matarazzo dedicou-se inicialmente à importação de alguns produtos alimentícios, organizando o seu primeiro emprendimento industrial somente 19 anos após a chegada ao Brasil .

Os quatro irmãos Jafet, radicados em São Paulo entre 1887 e 1893, dedicaram-se durante anos ao comércio atacadista e à importação de tecidos, decidindo-se a manufaturar tecidos apenas em 1906. Os Klabin e Weizflog tambem teriam importado papel por muito tempo antes de começar a produzi-lo (104).

(102). - Warren Dean, ob. cit., p. 26.

(103). - Idem, ibidem, p. 34/35.

(104). - Idem, ibidem, p. 37. 
A idéia do self-made-man em sua configuração completa tambem não ocorreria em São Paulo, a despeito de todas as esperanças, capacidade de trabalho e disposição de "fazer a América" com que naturalmente então acorreram os imigrantes ao Brasil. Aqueles que se tornaram empresários contribuintes do desenvolvimento industrial paulista pertenciam quase sempre à classe média da Europa e possuiam instrução técnica ou ao menos certa experiência no comércio ou na manufatura. Houve os que vieram contratados como técnicos ou administradores em empresas dos fazendeiros. Giovanni Briccola, por exemplo, cuja fortuna em 1911 orçava por volta de 5 milhões de dólares, chegara ao Brasil em 1885 contratado como engenheiro da Companhia Paulista de Estradas de Ferro. Francisco Matarazzo, filho de um funcionário público de Castellabate, no Golfo de Salerno, já detinha uma certa experiência comercial ao transferir-se para o Brasil (105).

Conviria lembrar que esses homens de negócios, tais como Matarazzo, Jafet, Scarpa, para só citar alguns, demonstraram aguda percepção das possibilidades que a vida econômica paulista oferecia naquele momento. Importante seria ainda salientar que na construção de seus impérios industriais e financeiros

"tiveram sempre o cuidado de não depender de agentes no Brasil ou no exterior para o capital básico ou para os passos essenciais no processo industrial" (106).

Suplementariam os fatores que influiram positivamente na industrialização do período em análise a facilidade de obtenção de crédito bancário que se observou nos anos posteriores à primeira valorização do café e a política fiscal do governo que, embora sem intençāo protecionista, fazia vista grossa, de maneira geral, à contribuição potencial dos manufatores.

Por outro lado o mercado paulista expandia-se geograficamente, desligando-se e tornando-se independente do do Rio de Janeiro: o Vale do Paraiba declinara, o porto da Guanabara cobrava das mercadorias uma taxa federal de $2 \%$ sobre o valor ds mesmas, taxa que era ignorada pela Companhia Docas de Santos, propriedade de particulares. As ferrovias atrairam o mercado do norte do Paraná, sul de Mato Grosso, Triângulo Mineiro e a área servida pela Rede Sul-Mineira.

Esse entrelaçamento de circunstâncias expandiria o parque manufatureiro, grandemente impulsionado com a deflagração da Primeira Guerra Mundial.

(105). - José de Souza Martins, Conde Matarazzo, o empresário e a empresa, São Paulo, 1973.

(106). - Richard Morse, ob. cit., p. 305. 
Dificultando as importaçōes o conflito provocaria as tentativas de substituição das mesmas. Basta lembrar que, entre 1915 e 1919, criaram-se no Brasil 5.936 estabelecimentos industriais (107).

De modo geral pode-se dizer, porem, que a proteção mais efetiva concedida à indústria residia na depressão cambial que, dificultando os meios de pagamento no exterior para os produtos consumidos por uma população em continuado crescimento, constituia-se em forte emulação ao fabrico dos mesmos.

Esses estímulos aleatórios em relação à indústria decorriam de uma política que, promovida pela elite rural, valorizava a atividade agrícola e, em um círculo vicioso, fortalecia essa mesma elite. Era manifesta a consciência de classe da elite rural e evidente a ação desses proprietários rurais que dirigiram a passagem de uma agricultura de grande lavoura do início do século XX para o complexo sistema industrial de meados desse mesmo século.

A despeito de seu contínuo crescimento até 1920 , o setor industrial foi marginal no âmbito de uma economia voltada para a exportação, raramente manifestando os seus representantes atitudes de oposição aos fazendeiros, o que implicava na ausência de uma ideologia explícita do industrialismo. Natural que assim fosse, dado o entrelaçamento de interesses entre grupo agrário e industrial, a coesão e força manifestas do primeiro bem como a dependência da indústria em relação à agricultura cafeeira.

Contudo, nessa época em que já havia grandes interesses investidos no setor industrial, passaria a ter ele um desenvolvimento mais lento, atribuivel à concorrência de importações estrangeiras que se observa após o conflito mundial, ao declínio da renda das exportações, à escasses de energia elétrica provocada pela seca de 1925 , à política deflacionária do governo federal.

Essa ocorrência, em contraposição à expansão cafeeira registrada, vem pôr em evidência o fato de que o papel desta última já não é tão relevante e tornar-se-á, posteriormente, cada vez menos significativo no desenvolvimento industrial paulista.

As dificuldades encontradas pelos industriais nos anos 20 expressar-se-iam na exacerbação de seus conflitos com outros setores da economia. Ả medida em que se tornava mais difícil a obtenção de lu-

(107). - Cf. Caio Prado Júnior, História Econômica, p. 267.

Warren Dean defende a idéia polêmica de que a guerra não propiciou a ampliação da capacidade produtiva e chega a indagar "se a industrialização de São Paulo não se teria processado mais depressa se não tivesse havido guerra" (Warren Dean, ob. cit., p. 114). 
cros, fazia-se mister racionalizar as atividades, o que levava inevitavelmente a uma visão mais precisa da eficiência alheia. Assim, "entraram a pensar em função dos seus interesses de grupo em oposição aos interesses dos outros", o que favoreceu uma coesão e consciência próprias.

Essa consciência, difusa, a princípio, e tímida ante a força do grupo agrário, afirmar-se-á com maior clareza a partir de 1930, quando os industriais paulistas se impõem como distinto grupo econômico, progressivamente mais importante do que as elites rurais e mercantis de que sairam.

O período anterior, contudo, é que alargaria o caminho.

Se quiséssemos sistematiza-lo mais didaticamente poderíamos lembrar a periodização estabelecida por Aziz Simão (108): um surto que, a rigor, já se inicia em 1870 e que sofre solução de continuidade entre 1897 e 1900 , quando a crise financeira provoca o fechamento de muitos estabelecimentos e a redução de atividade de outros; a retomada do crescimento a partir de então, num expressivo aumento de atividades que, em 1913, chega a superar a capacidade do mercado disponivel, o que concorre para nova crise que marca o término da segunda fase; de 1915 em diante, especialmente nos primeiros cinco anos, acelera-se novamente o ritmo da produção, com a redução da concorrência estrangeira por efeito da guerra que, se levanta dificuldades a alguns ramos industriais dependentes de importação de determinadas matérias-primas, favorece outros. Basta lembrar que, entre 1915 e 1917, criam-se em São Paulo 323 estabelecimentos industriais; na década de 20, embora não se interrompa, ralenta-se o ritmo, devido, entre outras, às dificuldades criadas pela concorrência externa já restabelecida que canaliza parte das disponibilidades provenientes do alto preço e do aumento das exportações de café.

Em 1929 São Paulo dispunha de 9 mil estabelecimentos industriais. Predominavam as indústrias téxteis e de alimentação (109). A crise deflagrada nesse ano afeta por breve tempo a indústria; logo depois retomaria ela o ritmo que transformou São Paulo no maior parque fabril da América do Sul.

A composição social do empresariado paulista do período mostra que a quase totalidade dos empresários nascidos no Estado pro-

(108). - Aziz Simāo, ob cit., p. 18/20.

(109) . - Em 1928 havia 247 estabelecimentos téxteis que empregavam... $41,46 \%$ do total do operariado. A seguir, em importância, a indústria de alimentos, ocupando $13,35 \%$ da força de trabalho (Cf. Aziz Simão, ob. cit., p. 46). 
vinha da elite rural. A seu lado há os imigrantes portadores de algum capital ou de experiência anterior em manufaturas ou comércio.

O crescimento industrial intensificaria o aumento da população ligada ao setor.

Em relação aos operários, só no ramo da indústria textil e na realidade o mais importante, empregava-se em 1900, cerca de 4.579. Dez anos depois esse número subira para 13.396 , e para $17.823 \mathrm{em}$ 1920 .

Em 1928 havia 148.376 operários nas indústrias paulistas em geral, quase o dobro dos 84 mil que existiam em 1920 (110).

A localização espacial dos estabelecimentos ocorreria nas áreas de maior expansão econômica: os municípios do oeste. Contudo era para a capital que iam as preferências mercê da situação geográfica, da ligação ferroviária com o planalto interior e o porto de Santos, da vantagem de ser a sede administrativa do Estado.

Já em 1907 contavam-se nela 153 estabelecimentos e 14.614 operários, representando respectivamente $46 \%$ e $63 \%$ dos totais do Estado (111).

Esse operariado compunha-se em grande parte de imigrantes europeus e seus descendentes. Muitas das levas chegadas para a cafcicultura não se fixaram na zona rural (112) e alem disso, muitas vezes, o mercado de trabalho rural era para esses imigrantes uma simples via de acesso a outras oportunidades de ação econômica, principalmente nos núcleos urbanos que se criavam. Assim é que, em 1920 , os 200 mil imigrantes do município de São Paulo, de que metade era italiana, constituiam $1 / 3$ da população local e $1 / 5$ dos estrangeiros existentes no Estado (113).

Quanto às condiçōes de trabalho, dificilmente se poderiam considerar favoráveis, se nos lembrarmos de que a reinvindicação de normas do direito público restritivas do arbítrio pessoal no estabelecimento do regime de trabalho resultaria da ampliação da própria experiência social dos assalariados. Estes, até ali, năo haviam conhecido outra forma de relações de produção, a não ser aquelas baseadas em tratos estipulados no âmbito da ordem econômica privada.

(110). - Aziz Simão, ob. cit., p. 14.

(111). - Idem, ibidem, p. 14.

(112). - Dados referentes a 1898 revelam que dos 27.214 elementos entrados na Hospedaria dos Imigrantes, 3.221 ou cerca de $12 \%$ ficaram na Capital e 525 em outras localidades u:banas (Cf. Aziz Simão, ob. cit., p. 29).

(113). - Aziz Simão, ob. cit., p. 29. 
Poucas eram as indústrias que dispunham de instalações especialmente construidas e em adequadas condiçōes higiênicas de trabatho. Mal iluminadas e ventiladas empregavam fartamente mulheres e crianças, computando-lhes menor remuneração do que aos homens.

Jornadas de dez horas de trabalho ou mais, durante 6 dias da semana, amiudavam os acidentes e os erros na produção, punidos com multas para os adultos e surras para as crianças.

Desde muito cedo se apontaria o desnivel entre salários e preços,

"de tal modo que mesmo o trabalho intensivo de mulheres e crianças, năo permitia mais do que o provimento mínimo da subsistência, pelo menos para a maioria do proletariado" (114).

Inexistia o contrato de trabalho com garantias legais: admissão e demissão do operário eram resolvidas verbalmente, sem aviso prévio ou indenização.

A legislação referente às condições de trabalho na zona urbana teve esporádica atenção do governo nos primeiros vinte anos do século, só se verificando um maior cuidado na década de 20 , quando o crescimento da indústria, estágio alcançado pelo movimento operário, a diversificação dos grupos sociais, as agitações que se verificam naquela fase, provocam modificações.

Em 1919 sanciona o governo federal a primeira lei dispondo sobre as obrigações patronais resultantes de acidentes de trabalho, criando em 1923 o Conselho Nacional do Trabalho, reorganizado em 1928, ao qual era conferida a competência de julgar processos relativos a questōes de trabalho.

No ano de 1925 promulgar-se-ia a lei de férias remuneradas para o assalariado urbano, consolidando-se em 1927 as leis de assistência e proteção aos menores (115).

Essa legislação sofreu resistência, não conseguindo encontrar desde logo condições de execução. Na primeira fase da industrialização predominava, quando muito, o paternalismo nas relaçōes entre trabalhadores e empresários, paternalismo que, quando consciente, se tornava uma forma de exploração racional da mão-de-obra. Jorge Street, por exemplo, industrial que proporcionava inúmeros benefícios aos operários de sua fábrica da Vila Maria diria que não o fazia a título de caridade mas em lugar de salários mais elevados

(114). - Idem, p. 64.

(115). - Aziz Simão, ob. cit., p. 79. 


\section{$-466-$ \\ "que seriam torrados em coisas inúteis" (116).}

Quanto ao operariado, a despeito da inexperiência social que lhes dificultava a reinvindicação de direitos, tentou, paulatinamente, desencadear um processo de pressão no sentido de melhorar as relaçōes de produção estabelecidas.

Utilizaria a greve como técnica fundamental, podendo-se registrar 91 ocorrências desse tipo, só na Capital, entre 1901 e 1914 (117). No período de 1915 a 1919 ocorreram, ainda na Capital, 42 conflitos em estabelecimentos isolados, destacando-se mais as greves gerais de 1917 e 1919 que atingiriam tambem o interior, evidenciando a nova arregimentação de forças sociais.

As reinvindicações dos operários incluiam geralmente aumento de salários de acordo com o aumento do custo de vida, reduçāo de horas de trabalho, formas de pagamento, proteçāo contra acidentes de trabalho.

A liderança mais efetiva desses movimentos caberia nas duas primeiras décadas do século aos anarquistas que abundavam no grupo de origem italiana. Os comunistas, cujo Partido apareceu no Brasil em 1922 , buscariam orientar o movimento operário e os conflitos coletivos no sentido de subordina-los à política partidária .

A reação dos industriais a essa movimentação era geralmente peremptória e pesada. Após as graves de 1917 e 1919 o Centro das Indústrias de Fiação e Tecelagem de São Paulo, através de seu secretário-geral, procurou obstar as açōes dos sindicatos que, a despeito da instabilidade que os caracterizou nos primeiros tempos, já se contavam em número de 91 nessa época (118).

Sua idéia mais inspirada foi a de uma lista negra, util para

"limpar a força de trabalho de elementos indesejáveis que operam dentro dela em certas ocasiōes como fermento de indisciplina" (119).

Ampliaria ainda a ação compilando dossiês de trabalhadores de modo que se pudesse averiguar-lhes continuamente a fidedignidade e a possibilidade de impedir os grevistas de encontrarem empregos em outras fábricas.

(116). - Apud Warren Dean, ob cit., p. 168.

(117). - Aziz Simäo, ob. cit., p. 105.

(118). - Idem, ibidem, p. 169.

(119). - Apud Warren Dean, ob. cit., p. 176. 
Gradativamente, as divergências e conflitos iriam compelir industriais e trabalhadores a se definirem mais claramente, a organizarem-se, adotando atitudes configuradoras de classes sociais distintas.

A expansão das atividades geradas pelo café, e sobretudo o desenvolvimento industrial no período intensificando o aumento das populações citadinas intensificariam o processo de urbanização do Estado. O fenômeno é especialmente visivel na cidade de São Paulo.

Não é facil caracterizar resumidamente o padrão de crescimento da cidade a partir de 1890. Um estudioso do assunto (120), em cujos dados nos apoiaremos para as informaçöes que se seguem, lembrara que a expansão geográfica da cidade se fará aceleradamente no período em análise.

Nos primeiros anos do presente século dois importantes blocos a constituiam: tendo como divisor a várzeas do Tamanduateí o velho centro e os bairros da zona oeste, sudoeste e sul contrapunham-se ao Brás e seu prolongamento no rumo do Leste.

O tradicional Triângulo formado pelas ruas Direita, São Bento e $\mathrm{XV}$ de Novembro ainda presidia o centro de vielas tortuosas e estreitas onde

\footnotetext{
"se processavam os negócios políticos e comerciais, trabalhava o cérebro e batia o coração de São Paulo" (121) .
}

Acentuava-se o fenômeno já esboçado na segunda metade do século anterior e configurado com nitidez ao final dos anos vinte: o da definição das áreas funcionais da cidade.

A área comercial localizava-se no velho Centro, sobretudo aquela representada pelo comércio varejista, já que o atacadista se instalaria de preferência nas vertentes do Tamanduateí. Se tomarmos por base um Almanaque de 1883, já mencionado em páginas anteriores e compararmo-lo com o ano de 1921-22 veremos que as 547 casas fornecedoras de alimentos e bebidas que aparecem na primeira data já seriam 2.517 na segunda. Tambem as lojas de fazenda que, de 70 unidades, passaram a 513 .

Havia ao todo cerca de 10.000 casas comerciais, observando-se uma diversificação indicadora não só do crescimento dos padrões de consumo como do refinamento dos mesmos: 219 casas de móveis, 36

(120) . - Pasquale Petrone, "A cidade de São Paulo no século XX", Revista de História no 21/22, São Paulo, 1955.

(121). - Gaffre, L. A., apud Pasquale Petrone, ob. cit., p. 136. 
de brinquedos, 86 joalherias, 32 relojoarias, 62 papelarias, 15 casas importadoras de automóveis (122).

O setor financeiro tambem se localizava no Centro, contando nessa época com 30 estabelecimentos bancários.

A zona industrial, já definida, acompanhava as vias férreas, atraida pelo baixo preço dos terrenos de várzeas próprios desses bairros Brás, Belenzinho e Mooca eram os mais característicos.

Uma terceira área funcional completaria o quadro urbano: a residencial. Afastada do Centro, já se faria distinguir quanto à composição sócio-econômica em três núcleos: o dos grupos médios: representados mais destacadamente pelos elementos das profissões liberais (123) e localizado na periferia do Centro ou em pontos mais afastados; o dos bairros operários adjacentes à zona industrial e o dos bairros "nobres" que, avançando através de Higienópolis (124) alcançam o espigão da Paulista e prosseguem rumo sudoeste em direção aos nascentes bairros-jardim (125) .

Em decorrência especialmente da função industrial, que no dizer de um estudioso tornaria São Paulo notavel exceção ao padrão latino-americano de cidade (126), a população aumentaria rapidamente.

Assim é que a década final do século XIX, período áureo da imigração européia, quadruplica a população. Em 1905 já havia 300 mil habitantes, 375 mil em 1910 e 472 mil em 1915.

O recenseamento de 1920 daria ao município uma população de 579.033 habitantes, num aumento médio de 70 mil elementos nos dois primeiros quinquênios e de 100 mil nos dois últimos, explicando-se tal oscilação pelo crescimento ou diminuição da corrente imigratória: no período de crise que antecede à primeira valorização do café há a queda de entrada de estrangeiros e o retorno de muitos deles ao passo que de 1910 a 1915 , por exemplo, revigora-se a imigração.

(122). - Cf. Pasquale Petrone, ob. cit., p. 152.

(123). - Por volta de 1925 havia em São Paulo 500 advogados, $410 \mathrm{mé}$ dicos, 320 dentistas, 220 farmacêuticos, 176 engenheiros e arquitetos (Cf. Petrone, ob. cit., p. 153).

(124). - Higienópolis destronara os Campos Elíseos tornando-se nesse periodo o bairro mais elegante da cidade.

(125). - Os bairros-jardins foram introduzidos a partir de $1915 \mathrm{com}$ a construção do Jardim América. Caberia à Companhia City, de capitais ingleses, a iniciativa, ao comprar grandes áreas baixas e desvalorizadas antes. da Primeira Guerra Mundial. Investindo elevadas somas em terraplanagem, arruamento e pavimentação, elitizaria tais bairros em função das restriçōes que impunha às edificações.

(126). - Richard Morse, ob. cit., p. 238. 
Ao findar o primeiro quartel do século, com 800 mil habitantes, tornara-se São Paulo a segunda cidade brasileira e a terceira da América do Sul em população.

Seu cosmopolitișmo era evidente, abundando o elemento europeu, especialmente o peninsular. Destes, aqueles que fariam alguem caracterizar São Paulo como uma "cidade de italianos" (127) teriam um bairro preferenciạl: o Brás. Essa preferência dar-se-ia provavelmente dos meados da década de 90 em diante, apesar de imigrarem desde 1870 .

Pode-se verificar que eram poucos ainda no início dos anos 90 . o Alistamento dos eleitores do município da Capital, realizado em 1891, arrola para o distrito do Brás 672 eleitores em oito quarteirões. Destes, apenas 30 eram de procedência italiana.

A expansăo da área urbana e o crescimento demográfico repercutem no desenvolvimento material da cidade e na sua fisionomia pelas naturais e crescentes exigências de habitações e as consequentes reinvindicações de melhoria e progresso nos serviços de utilidade pública.

As 21.656 edificações de 1900 ascendem a 32.914 em 1910 num ritmo de mil construçōes por ano

- "ao terminar a segunda década o total já atingia quase $60 \mathrm{mil}$, o que corresponde a um aumento très vezes maior ao registrado no período anterior, com a média anual de 3.000 prédios" (128).

A maioria das novas construções, tanto públicas quanto particulares-trazia a marca da arquitetura italiana em estilo néo-clássico ou floral. O Teatro Municipal, por exemplo, que Ramos de Azevedo construiu entre 1908 e 1911, bem como o edifício da antiga Escola Normal, hoje Caetano de Campos, obedeciam às linhas do néo-clássico italiano.

Notava-se ainda outra característica, que viria a ser um aspecto distintivo e altamente identificador da cidade: o dos altos prédios, assinalado pitorescamente por um estrangeiro que aqui esteve na década de 20:

"durante estes últimos anos os paulistas e os italiznos tomaram-se de frenético desejo de tocar o céu com os dedo:"...

(127). - Apud Pasquale Petrone, ob. cit., p. 144.

(128). - Pasquale Petrone, ob. cit., p. 145. 
Referindo-se à aquisiçāo que o Conde Matarazzo fizera de um terreno próximo ao Municipal com vistas à construção de um edifício dizia que ele o fizera para

"ultrapassar em altura aqueles que já habitavam as nuvens" (129) .

A partir de 1922 registra-se a expansão da iluminação elétrica que, iniciada pela Light nas vias públicas em 1916, eliminaria em poucos anos a pitoresca figura do acendedor de lampiōes a percorrer pontualmente a cidade ao anoitecer.

Em relação aos transportes urbanos, apesar de em 1918 a cidade contar já com 1.234 automóveis particulares, 586 de aluguel e 157 veículos de carga, bem como algumas linhas de bondes elétricos (130) predominariam nos primeiros 25 anos do século atual os veículos movidos a tração animal

Muitos desses melhoramentos deveram-se tambem a administraçōes operosas como foi o caso da do prefeito Antônio Prado em cuja gestão (1898-1908) se realizaram várias e custosas obras de saneamento, sobretudo na várzea do Tamanduateí e o ajardinamento de praças como a da República.

A vitalidade que se fazia sentir em todos os setores repercutia tambem na Imprensa da Capital onde circulavam cerca de 139 jornais, à frente dos quais se colocavam $O$ Estado de Sāo Paulo, $O$ Diário Popular, A Gazela (131).

Ao terminar a Primeira República, a "metrópole do café" já preparara o caminho para o slogan que se faria frequente posteriormente: o da "cidade que mais cresce no mundo".

Era o reflexo da pujança econômica do Estado a colocar São Paulo à frenie das demais unidades da Federação, fato expresso em eloquentes números: se, como já foi mencionado, o Brasil possuia em janeiro de 1932, em números redondos, $121 \mathrm{mil} \mathrm{km}$ de estradas de rodagem, a Săo Paulo caberia a 4a. parte. De 1890 a 1930 a população total brasileira aumentou de menos de três vezes ao passo que a do Estado de São Paulo se multiplicou por quatro vezes e meia.

(129) . - A. L. D'Atri, L'Etat de Säo Paulo et le Renouvellemente Economique de L'Europe, Paris, 1926, p. 208.

(130). - Em 1921 a Light tinha em serviço 407 bondes de passageiros (Cf. Pasquale Petrone, p. 150).

(1i1). - A. L. D'Atri, ob. cit., p. 196. 
A rede ferroviária paulista fora acrescida de $145 \%$ elevando-se o tráfego no transporte de passageiros cerca de 7 vezes e 6 vezes no de mercadorias. Enquanto as receitas brutas subiam na proporção de 7 vezes as rendas líquidas iam a 5 vezes.

Enquanto o valor da produção agrícola do Brasil em 1930 era de 4.732.705 contos, estimava-se a de São Paulo em 3.335.080, concorrendo portanto a lavoura paulista com mais de $70 \%$ do valor total das safras do país.

Não menos vultoso seria o desenvolvimento do comércio externo e interno do Estado: enquanto no Brasil o valor desse comércio aumentara, de 1926 para 1928 em cerca de $15 \%$, crescera em São Paulo de $38 \%$.

Ocorria o mesmo na arrecadação das rendas públicas - as receitas brasileiras arrecadadas em 1923 atingiram 2.163.587 contos de réis e 4.031 .137 contos em 1929 num aumento de $85 \%$. Em São Paulo foram de 504.182 no primeiro dos anos mencionados e de 1.243 .736 contos de réis no último, cerca de $145 \%$ a mais:

"a capacidade tributária da população do Estado de São Paulo era patente. Cada habitante do Brasil concorreu com um aumento de pouco mais da metade para as despesas públicas no período considerado - o paulista deu o cobro" (132).

O crescimento contínuo e significativo desses índices da riqueza pública evidenciavam uma pujança econômica quબ, dinamizada pela ação política, assinalaria a sincronia entre o poder político e o econômico que caracterizou a história de São Paulo no perígdo da República Velha.. O regime federativo dando maior flexibilidace à elite agrária, permitiu que o poder, exercido em nome de toda a mação, se concentrasse no setor cafeeiro.

A recem-inaugurada ordem política garantiu aos Estados o direito de contrair empréstimos no exterior, decretar impostos de exportação, reger-se por suas próprias constituiçóes, possuir corpo: militares próprios, assim como códigos eleitorais e judiciais:

- "os inúmeros direitos estaduais compunhm a seção intocavel da Constituição Republicana" (133).

(132). - Eugênio Lefevre, ob. cit., p. 436.

(133) . - Maria do Carmo Campello de Souza, "O process político-partidário na Primeira República", Brasil em Perspectiva, São Palo, 1969, p. 164. 
o que conferiria grande importância aos Estados; cabendo a hegemonia, como decorrência natural, aos mais poderosos economicamente.

Alcançando São Paulo a almejada liberdade negada pela centralização monárquica, tudo se faria no sentido de favorecer-lhe a hegemonia política: a Constituição de 91 estabeleceu a proporcionalidade de representação na Câmara Federal em relação à população quando São Paulo já era um dos Estados brasileiros mais populosos, alem do sufrágio universal e da eleição presidencial direta pela maioria de votos, com exceção do primeiro período presidencial.

Ora, essa extensão do voto à população, que teoricamente representaria a possibilidade concreta de participação da massa eleitoral no processo político, revelar-se-ia na prática uma benesse a mais para a classe dirigente que a utilizaria como meio de manter a eficácia e validade de sua posição perante a coletividade - a função eleitoral do "coronelismo", condutor da massa votante por ele dominada permitiria a montagem de sólidas e estáveis máquinas eleitorais que reforçariam o poder dos grupos estaduais dirigentes, a refletir-se no plano federal.

Pode-se assim dizer que os Estados adquirem condições para, dotados dos necessários suportes legais dominarem a política nacional, funcionando as três grandes coordenadas da Primeira República federalismo, presidencialismo, ampliação do regime representativo em correspondência zom o desenvolvimento e as necessidades do polo dinâmico da econonia, vale dizer, de São Paulo especialmente.

A prática do regime federativo não se faria sem ajustamentos em que as disputas pelo poder exigiram a intervenção de forças militares mas, consolidada a República, a primeira série de presidentes civis que a dirige, todos paulistas já evidencia a preeminência de São Paulo no plano federal.

A "política dos governadores", iniciada por Campos Sales, acentuaria o processo: em troca de total autonomia, com os dirigentes dispondo de carta branca para agir sem qualquer intervenção da União, os Estados daram ao presidente da República o apôio que the permitiria a garania e prática do poder. Essa combinação, implantando oligarquias estuduais impermeáveis a eventuais tentativas oposicionistas de ascensã ao poder garantiria a São Paulo uma expansão econômico-política mais livre ainda, o que, em círculo vicioso e, a despeito de compromiso de apôio ì União, permitia-lhe a condução da política nacional.

Mais anda: a política do "café com leite" iniciada em 1906 com Afonso Pen: e determinando o revezamento de candidatos à Presidência da Repiblica apontados por São Paulo e Minas Gerais amplia o 
quadro de indicaçōes sobre a importância política paulista no plano federal.

Dentre essas indicações são ilustrativas aquelas que se referem a manifestações ditadas pelo ressentimento de outros Estados, havendo quem se queixasse de que,

"mesmos nos municípios mais recuados do Norte, só eram eleitos vereadores os elementos simpatizantes dos paulistas" (134).

Epitácio Pessoa representando a Paraiba no Congresso Constituinte já anteveria e evolução do processo ao discutir a questão da representação parlamentar na Câmara Federal advertindo:

“... Pelo modo porque a Constituição estabeleceu a representação dos Estados - Senado e Câmara - é fácil verificar que 4 ou 6 Estados podem, eles só, decidir os negócios que dizem respeito aos 20 ou 21 Estados que compõem a União...". E ainda: no Brasil, "os Estados grandes disputarão entre si a geração dos negócios públicos e os Estados pequenos, arrastarão uma vida inglória, obscura, não hão de ter a mínima interferência nos negócios de nossa pátria, hăo de ser sempre esmagados pela enorme superioridade com que aos outros dotou a Constituiçāo do país..." (135).

Essa superioridade é assinalada quando Hermes da Fonseca, no governo da República, busca a derrubada das oligarquias estaduais com o fito de substitui-las por outros tantos grupos semelhantes, porem de sua confiança. As "salvações" não atingiram São Paulo, justamente o Estado que mais motivos de intervenção oferecia ao governo federal, uma vez que havia sido o sustentáculo de Rui Barbosa, o candidato civilista e continuava, no início do governo Hermes, a fazer-lhe oposição (136)

- "São Paulo não era como os Estados do Norte, terra de ninguem" e por isso ali, "tudo terminou como em opereta" (137).

(134). - M. Isaura Pereira de Queiros, $O$ mandomismo local na vida politica brasileirá, São Paulo, 1969, p. 103.

(135). - Apud Maria do Carmo Campello de Souza, ob. cit., p. 190.

(136). - "O sentido anti-oligárquico do governo Hermes perde um pouco de sua força quando se atenta para o fato de que as intervençōes não tocaram nos grandes redutos, símbolos mais patentes de uma ordem, que supostamente se pretendia mudar: São Paulo Minas Gerais e Rio Grande do Sul" (M. do Carmo Campello de Souza, ob. cit., p. 223).

(137). - Apud Maria Isaurà P. de Queiroz, ob. cit., p. 103. 
Da primazia de São Paulo durante a Primeira República não são exemplo apenas os presidentes paulistas que governaram o país.

Desde cedo outros postos de importância na vida republicana nacional foram ocupados por eles. Rangel Pestana seria presidente do Banco da República do Brasil em 1895, Bernardino de Campos, Ministro da Fazenda em 1897, Cincinato Braga, à frente do Banco do Brasil em 1926, Pedro de Toledo, ministro da Agricultura, Indústria e Comércio em 1910, no período hermista, entre muitos outros.

A hegemonia política de São Paulo no período analisado decorre, repetimos, da identificação do governo com os interesses de uma classe: a agrária, em favor de cujas necessidades e desenvolvimento desenrola-se toda a ação federal. Seria a fase do "império dos fazendeiros", detentores, nāo só do produto que representava a riqueza nacional e pagava as despesas da nação, como do comércio, dos Bancos, meios de transporte, da organização da mão-de-obra, enfim de toda a vida econômica.

São inúmeras as manifestaçōes do poderio e da influência dessa classe sobre o governo, ele próprio exercido em várias ocasiōes por fazendeiros de café, como no caso dos três primeiros presidentes civis do país.

Seria ela o vetor ideológico (138) e pragmático de uma política que, mesmo quando discordante, curvar-se-ia a suas imposições. No caso, por exemplo, da introdução de japoneses em São Paulo, mostrava-se o governo relutante, em decorrência talvez dos preconceitos vigentes então e que consideravam tais imigrantes inassimiláveis, portadores de cultura diferente e sobretudo, de fatores étnicos que muitos repeliam (139).

No entanto,

"a pressão constante dos fazendeiros de café junto ao governo fez com que este concordasse com a introdução de japoneses" (140).

(138). - Quando ministro da Fazenda em 1897 escreveria Bernardino de Campos: - "nos paises novos, a maior soma de recursos materiais há de provir forçosamente da cultura do solo, que fornece os produtos mais necessários à vida da população" (Apud Nícia Vilela Luz, "Aspectos do nacionalismo econômico brasileiro", Separata da Revista de História, São Paulo, 1954, p. 144).

(139). - A respeito da introdução de asiáticos diria Basílio de Magalhães por volta de 1913: - "porquanto afora outros inconvenientes viriam abaçanar e afeiar a nossa raça que tende cada vez mais a embranquecer e alindar-se, mercê do cruzamento com cativos e saxões, notadamente na vasta e progressiva região meridional de nossa Pátria que é onde já estão fixados e em portentosa progressão os melhores elementos étnicos..." (Basílio de Magalhães, ob. cit., p. 72/73).

(140). - Arlinda Rocha Nogueira, ob. cit., p. 228. 
no Estado de São Paulo, a despeito de faze-lo em carater experimental.

As valorizações do café tambem foram resultado da ação direta dos Estados produtores, especialmente São Paulo, por força do interesse dos grupos agrários. Dessa maneira, tomaram conta de um instrumento de mando, de molde a assegurar-lhes a proteção econômica de que necessitavam. Nesse sentido, as normas liberais que regiam o quadro político e econômico brasileiro eram esquecidas ou afrouxadas, sabendo a classe dirigente, quando necessário, reformular o princípio do Estado näo intervencionista, como no caso da defesa dos preços do café.

Em 1921 os fazendeiros novamente persuadem o governo federal a comprar quase um terço da safra do café, favorecendo-os ainda a política inflacionária da época:

"Durante a primeira guerra mundial e nos cinco anos subsequentes puderam os fazendeiros pagar suas dividas sem maiores dificuldades, mercê da maciça emissão de papel-moeda a que se entregava o governo. Sempre sensivel às exigências dos fazendeiros, adotou o Partido Republicano Paulista uma implacável política de emissões e crédito facil no Congresso Federal". (141).

Pode-se ainda verificar que no período da primeira República

"os debates e projetos apresentados e aprovados mostram a tendência majoritária das classes agrárias" (142).

Alem do mais, como mostra Celso Furtado em sua Formação Econômica do Brasil e como já foi mencionado no correr destas linhas, não houve o aparecimento de uma insofismavel oposição entre as diversas esferas econômicas, de onde o império dos fazendeiros.

A política desenvolvida para a manutenção desse império geraria, porem contradiçōes que auxiliariam a sua derrocada e que se farão visíveis na década de 20 .

A defesa dos preços do café reformulando o princípio do não-intervencionismo estatal difundiria a idéia de que ao governo caberia a propulsão do progresso e o zelo pelo bem-estar e desenvolvimento de todo o país. Andando mal as coisas no resto do Brasil, imputar-se-ia o fato à

(141). - Warren Dean, ob. cit., p. 147.

(142). - Edgard Carone, A República Velha (Instituiçōes e classes sociais), São Paulo, 1970, p. 155. 
"excessiva descentralização que impedia o governo federal de desempenhar seu papel primordial de protetor e amparo dos mais fracos" (143).

f

Vai-se fazendo visivel o enfraquecimento das bases federalistas e a necessidade de reformulação do sistema político republicano. Prova? A revisão da Constituição, promovida pelo Executivo em 1926 e que ampliava as faculdades e direitos do governo central ante os Estados.

A dinamização da indústria revelada pela multiplicação dos centros industriais nos Estados no correr dos anos de vinte, espelharia o crescente poder do setor, visto com simpatia já por Epitácio Pessoa, de início seu adversário, e admitido como potência pelos governos de Artur Bernardes e Washington Luís (144).

Alem do mais intensificou a urbanização que por sua vez ampliaria os grupos urbanos médios, justamente a camada da população que tinha alguma possibilidade de conscientizar os impactos sofridos pela política econômica do governo. Esta, apesar de ter em mira a classe agrária, secundariamente por vezes satisfazia o grupo industrial.

Um desses impactos, por exemplo, foi a alta do custo de vida dos anos vinte que contribuiria para a inquietaçāo social

"já provocada: por transformações na estrutura da sociedade brasileira" (145).

Aliar-se-ia a esta inquietação o descontentamento face à corrupção e métodos políticos da Primeira República.

Nesse período foram as eleições por toda parte

"simples preenchimento feito por processos mais ou menos grosseiros, de uma formalidade; viam-se seç̧őes eleitorais ao abandono, livros manipulados nas casas dos coroneis que dirigiam â política municipal, turmas de candidatos diferentes apresentando-se diante do poder verificador, alegando ter vencido as mesmas eleições, falsificaçōes das atas das Câmaras Municipais que deviam designar os efetivamente eleitos..." (146).

(143). - Maria Isaura Pereira de Queiroz, ob cit., p. 126.

(144) . - Nícia Vilela Luz, "A década de 1920 e suas crises", Revista do Instituto de Estudos Brasileiros ño 6, Săo Paulo, 1.969, P. 69/70.

(145). $\div$ Idem, ibidem, p. 71.

(146). - M. Isaura P. de Queiroz, ob cit., p. 101. 
Aliás, a esse respeito e dez anos somente após a implantação do regime, um republicano histórico, irmão do chefe de Estado, comentaria amargamente:

- “... o país vai se precipitando cada dia na mais profunda decadência moral e política, quando é certo entretanto que o nosso intuito não foi outro, ao proclamar o novo regime, senão fomentar e garantir ao povo brasileiro a regeneraçāo de seus costumes, pelo amplo exercício de seus direitos e pela livre manipulação de sua consciência, dentro dos moldes de uma estrutura política em que o governo fosse a justa recompensa da superioridade do mérito e não um monopólio dos incapazes.

A federação $\ldots \ldots \ldots \ldots$. não tem sido mais do que um magnífico instrumento para a colocação de numeroso grupo dos audazes, cujo único fito tem sido até hoje a franca escalada ao poder e a mais torpe exploração do Tesouro. Do norte ao sul do país, os governos estaduais outra coisa não têm feito senão atirarem-se com fúria à mais desbragada delapidação dos cofres públicos" (147) .

Esse desabafo refletia as divergências que ocorreriam no seio do Partido Republicano Paulista, fruto de oposição, ainda que efêmera, ao situacionismo.

As primeiras já seriam notadas em 1890 com o lançamento da candidatura de Américo Brasiliense ao governo do Estado.

A essa dissidência seguir-se-iam outras como a de 1901 e aquela ligada à escolha de Altino Arantes para a sucessão de Rodrigues Alves, que terminava então o seu mandato de Presidente do Estado pela segunda vez.

Das dissidências chegamos às Ligas, como a Liga Nacionalista de 1917, resultante da campanha de civismo iniciada por Olavo Bilac e cujos argumentos críticos evoluem de razöes morais para atitudes políticas, com um enfoque social "principalmente mas nāo exclusivamente", no dizer de Júlio de Mesquita Filho.

Em 1925 surge a Liga do Voto Secreto, orientada por Plínio Barreto e Monteiro Lobato, tendo como uma das principais reinvindicaçōes a que lhe deu o nome.

Os desajustamentos e inquietaçōes sociais do período concretizam-se em reinvindicações políticas que favorecem a evolução das $\mathrm{Li}$ -

(147). - Alberto Sales, "Balanço político", O Estado de São Paulo de $18 / 7 / 1901$. 
gas para os Partidos que contestariam o predomínio absoluto das classes no poder - o Partido Democrático nascido em 1926 aglutina os dissidentes da ala oligárquica do Partido Republicano Paulista, mas apoia-se já nos setores médios urbanos. Estes últimos terão como um dos seus porta-vozes o grupo militar, não mais somente na qualidade de guardião da ordem institucional. A ocorrência de cisões na cupula civil dominante estimulava o setor militar a funcionar como árbitro, mas agora os militares mais jovens é que apoiarão e lutarão por um programa reformista. O movimento tenentista

"parece incorporar e de certo modo será o porta-voz da insatisfação da classe média urbana" (148)

a julgar pelo seu programa liberal que, em essência, será aquele defendido pelos grupos médios urbanos: eleições livres, voto secreto, administração honesta, etc., enfim, objetivos reformistas e regeneradores da nação e de seu regime republicano.

O movimento resolve-se especialmente em dois levantes militares: um em 1922 a partir do Forte de Copacabana no Rio de Janeiro e o outro em São Paulo no ano de 1924, com o apôio de oficiais do Norte e do Rio Grande do Sul, e que foi um dos pontos de partida da extraordinária aventura da Coluna Prestes.

A revolta de 22 sucederia uma repressão generalizada envolvendo todas as formas legais de oposição, num reforço às oligarquias dominantes, mas nem isso, nem a morte dos "dezoito do Forte" abalariam o ânimo dos tenentes que se articulam novamente e à falta da chefia civil que haviam buscado agrupam-se sob o comando do General Isidoro Dias Lopes para novamente em 1924 manifestar a sua insatisfação contra

"a política de campanário, formação de cabos eleitorais, panelinhas de mandões ineptos" (149).

A revolta dessas novas geraçōes de militares visando alterar as bases de uma situação política dominada pelo "voto a bico de pena", "voto de cabresto", enfim, pela inverdade eleitoral teve São Paulo por cenário, onde conta com o apôio do major Miguel Costa, oficial da Força Pública, então com efetivos e poder de fogo superiores no Estado aos do Exército.

A escolha de São Paulo para início do movimento, a ser seguido pelas outras unidades da Federação e decorrente do apôio que os revolucionários ali sentiam, revela a mudança e diversificação que se

(148). - Nícia Vilela Luz, $A$ década de $1920 \ldots$, p. 71.

(149). - Paulo Duarte, Agora nós!, São Paulo, 1927, p. 284/85. 
vinham fazendo sentir na composição social do Estado, sacudido pelas manifestaçōes preliminares da industrialização.

A 3 de julho de 1924 partia o general Isidoro do Rio de Janeiro para São Paulo, estourando na madrugada de 5 de julho a revolução que obrigaria o governador Carlos de Campos a abandonar os Campos Elíseos para refugiar-se em Guaiauna, próximo à Penha.

As ruas de São Paulo transformaram-se em campos de combate, mas os resultados eram imprecisos, carecendo ambas as partes de coordenação militar; a maioria dos oficiais tambem era estranha aos soldados, grande número dos quais, recrutas recentes e inexperientes (150).

Ilustrativo dessa inexperiência é o episódio narrado pelo coronel Arlindo de Oliveira, uma das principais figuras vivas do tenentismo, em O Estado de São Paulo de 5 de julho de 1974:

"O Batalhão Escola da Força Pública devia ser levantado por mim às 2 horas do dia 5 . Um pelotão do Exército, com 25 homens, deveria chegar à mesma hora, na Ponte Grande, para dar seu apôio. Chefiado pelo tenente Gwyer de Azevedo chegou às $6 \mathrm{e}$ meia da manhã, com apenas oito soldados. Quando descarregamos duas metralhadoras em frente ao portão do Jardim da Luz, fazendo pontaria para o Batalhão Escola, verificamos que o sargento havia esquecido a munição. $\mathrm{E}$ os soldados não tinham um cartucho sequer".

$O$ resultado de tais desencontros seria um esgotamento moral prematuro, resultando a resistência encontrada em certo ceticismo; a 28 de julho batem os rebeldes em retirada que se transformaria posteriormente na marcha da Coluna Prestes, a estender-se por $20 \mathrm{mil} \mathrm{km}$ do território nacional, que foi o caminho percorrido pelo "Cavaleiro da Esperança".

O governo federal, então sob Artur Bernardes, que vinha dirigindo o país sob o regime de estado de sítio, inicia a radicalização e as arbitrariedades, prendendo mais de 10 mil pessoas em São Paulo, acusadas de colaborar com os revolucionários, entre as quais Firmiano Pinto, José Carlos de Macedo Soares, Júlio de Mesquita e outras personalidades que sofreriam graves processos.

A despeito de por si só não serem suficientes esses movimentos para abalar o sistema de poder em vigor, representam o desejo de reforma à ação de um federalismo manipulado em favor de um grupo -

(150). - Edgard Carone, A República Velha (Evolução política). São Paulo, 1971, p. 374. 
o fazendeiro: significativos seriam os seus ataques à dominação política da oligarquia rural e ao latifúndio que lhe constituía a base de sustentação.

Essa contestação vai produzir seus frutos depois de 29 , quando a crise vem repercutir com grande impacto no mundo dos fazendeiros.

A alta de preços decorrente da última valorização, embora artificialmente sustentada pelos empréstimos de bancos estrangeiros incentivaria novas áreas de cultivo. A desorientação dos círculos financeiros, a retração de vendas e consequente queda de preços do café que se segue à quebra da Bolsa de Nova Iorque colocarão os agricultores em terrivel situação: dependendo dos empréstimos bancários para o custeio de suas lavouras veem-se subitamente sem esse auxílio. A baixa brutal da cotação do café, de $3 \$ 050$ para $1 \$ 800$ o quilo (151) coincide com o início da produção dos novos cafezais. O Banco do Brasil cancela as subvençōes ao Instituto do Café para a compra das "quotas de retenção".

A atitude de Washington Luís contrário à moratória e emissão para a compra de estoques leva os cafeicultores à situação crítica em que a insolvência é geral.

Desaba o "império dos fazendeiros", não mais reconstituido após a revolução de 30 à qual não faltaria, entre outros, o motivo político: a obrigação por parte de Washington Luís do "acordo entre cavalheiros", pelo qual, a um paulista sucederia um mineiro na presidência da República. A decisão de manter os paulistas no governo através da candidatura Júlio Prestes incita a desgostosa liderança de Minas Gerais a unir-se ao Rio Grande do Sul, fornecendo-lhe a oportunidade para reentrar no cenário político. A estes unem-se as dissidências dos demais Estados, que incluiam o Partido Democrático de São Paulo, numa Aliança Liberal em prol da candidatura Getúlio Vargas.

Iniciada a 3 de outubro de 1930 a revolução não encontrou em São Paulo a resistência esperada, em que pese o fato de ostensivamente ser um movimento contra a posse de novo presidente paulista: os agricultores, descontentes com o governo, mantiveram-se alheios; industriais queriam apenas "ordem e segurança" para se deesnvolverem, e sofriam as consequências de um programa deflacionário.

Os setores urbanos médios aplaudiriam a revolução que lhes parecia arrebatar o poder das mãos dos fazendeiros. Para os descendentes -de imigrantes incluidos nesses grupos, representaria ela, provavelmente,

(151). - Pierre Mombeig, Pionniers et planteurs, p. 103, 
a possibilidade de se integrarem mais fundamente, pela participação política, numa sociedade em que, de certa forma, ainda eram adventícios (152).

Após a revolução de 30 a agricultura abdica de sua ação própria (153) e o café perde a primazia, não antes de ter fornecido a possibilidade de transição do país para um tipo de economia mais integrada, em que o mercado interno é objeto de maior atenção. No quadro cafeeiro, embora incipientemente estruturado, encontraria o desenvolvimento econômico do Brasil a possibilidade de expansão a partir de 30, numa reformulação ainda das relações do Estado com um organismo econômico que passava a exigir atuação não somente sobre alguns focos regionais mais sobre as exigências do seu conjunto (154).

Essa reformulação, todavia, levaria a um quadro, em relação a São Paulo, de assincronia entre o poder político e o econômico que se mantem a partir de então.

\section{I I}

A perda do predomínio nos negócios públicos não impediria que após o primeiro impacto o crescimento de São Paulo, continuasse e, de forma acelerada.

A década de 30 caracterizar-se-ia pelos esforços de ajustamento do Estado às novas condições criadas pela crise de 29 e a derrocada do café.

O valor da atividade agrícola foi declinando e dentro dela o café, de vez que a crise não seria passageira - desde aquela época o consumo mundial atingira a um limite alem do qual só ascenderia lentamente, acrescendo-se ao fato a presença dos concorrentes, hoje numerosos e respeitáveis.

Ademais, no centro e oeste de São Paulo as terras começaram a dar sinais de cansaço, diminuindo sensivelmente a produtividade, prejudicada que foi pelos maus tratos a que os cafezais foram submetidos nos anos de dificuldades financeiras que se sucederam a 1930 e pela irrupção de pragas como a broca.

(152). - Maria Isaura Pe-eira de Queiroz, ob. cit., p. 123.

(153). - Para Otávio Ianni (O colapso do populismo no Brasil, Rio de Janeiro, 1968, p. 11), a revolução de 30 simboliza a liquidação do modelo de exportação de produtos tropicais e matérias primas e importação de manufaturas que caracterizou a economia brasileira das três primeiras décadas do século.

(154). - M. do Carmo Campello de Souza, ob. cit., p. 166. 
A maior extensão da lavoura cafeeira paulista foi atingida em 1932-33 quando o número de plantas atingiu 1.504.035.486 unidades. A partir de então e até agora esse número se foi restringindo (155).

Uma consequência desse declínio foi o parcelamento do latifúndio cafeeiro e o consequente desenvolvimento da pequena propriedade:

- "o exgotamento do solo, a queda de preços, as dificuldades de exportação, estes são os verdadeiios fatores que contam. $\hat{E}$ deles que provem a ruina das fazendas e grandes domínios e em consequência o seu retalhamento, último recurso para sair das dificuldades" (156).

O número de propriedades rurais paulistas que em 1930 era de 163.765 subiria a 180.472 em 1940 . No ano de 1950 os estabelecimentos de menos de 20 hectares acusavam um índice de $29,33 \%$ saltando para $46 \%$ em 1960. Todavia, as pequenas lavouras ainda representam reduzida parcela da riqueza fundiária paulista, mormente se se pensar no desenvolvimento da pecuária, feito à base de grandes latifúndios.

O ostracismo a que se viram condenadas as oligarquias agrárias com a revolução de 30 não significaria contudo equivalência de tratamento quanto ao produto a que elas se dedicavam.

Entre 1933 e 1938 , reassumindo a responsabilidade pelo problema do café, a União tomaria medidas para a sustentação do produto básico da economia brasileira:

- "na história do café nenhum governo tomou tantas medidas a favor da cafeicultura como Getúlio Vargas e os tenentes interventores, João Alberto e Waldomiro Lima" (157).

comprando e destruindo os estoques que se concentravam em mãos dos governos estaduais.

$\mathrm{Na}$ verdade essa drástica atitude era tambem resposta profundamente política: não sobreviveria o governo que naquele momento abandonasse os fazendeiros, possuidores de mais do que lavouras:

(155). - Caio Prado Júnior, História econômica do Brasil, p. 298.

(156). - Caio Prado Júnior, "Problemas de povoamento e a divisão da propriedade rural", Evoluçāo política do Brasil e outros estudos, São Paulo, 1957, p. 236.

(157). - "São Paulo e a economia brasileira", O Estado de São Paulo de $27 / 10 / 73$. 
eram os que controlavam o eleitorado rural. De fato, a queda política das oligarquias rurais não significava de pronto a quebra de predomínio do sistema agrícola.

Se a crise de 29 repercutiu de maneira tão sensivel deveu-se isso ao fato do Estado depender de uma economia fundamentalmente de exportação e embasada no café como, praticamente, o único produto. Contudo, ela favoreceria a caminhada para a quebra dessa estrutura monocultora, com a diversificação agrícola que se observará em São Paulo dessa época em diante.

Decorrente da necessidade de transferir rapidamente capital e trabalho para áreas que pudessem substituir, temporária ou permanentemente, a atividade em crise, fez-se com relativa facilidade, em resultado de circunstâncias históricas já aqui mencionadas: infra-estrutura criada pelo café (transportes, etc.) que poderia ser aproveitada para o desenvolvimento de outras produçöes.

A agricultura se diversifica rapidamente e, ao lado do café, o algodão, a laranja e cana-de-açucar terão o seu cultivo incentivado. $O$ algodão especialmente, desempenhará papel de importância, concorrendo com destaque no mercado exportador.

Intensificaram-se pesquisas e experiências para a obtenção de variedades selecionadas que oferecessem melhores fibras, através de um serviço especial que se criaria no Instituto Agronômico de Campinas.

A pecuária tambem se desenvolveu e, hoje, esseg dois setores, apesar de não representarem a maior parcela da economia paulista são de consideravel importância para as rendas do Estado. Segundo dados compilados pela Bolsa Review, orgão do Bank of London \& South America para uma análise da economia paulista realizada por essa publicação, São Paulo detem $30 \%$ da produção agropecuária total do país, colocando-se em primeiro lugar entre os demais Estados nesse setor.

A área contudo em que com maior exito se fez a transferência dos fatores de produção foi a da indústria. A grande característica de São Paulo após a revolução de 30 será, do ponto de vista econômico, a de se ter tornado um Estado predominantemente industrial.

$\mathrm{Na}$ década de 30 a produção industrial começará a superar em valor a atividade agrícola. Crise, o baixo preço do café, diminuição da renda monetária interna, encarecimento de mercadorias estrangeiras, explicam que

"ao manter-se a procura interna com maior firmeza que a externa, o setor que produzia para o mercado interno passa a 
oferecer melhores opotunidades de inversão que o setor exportador. Cria-se em consequência uma situação praticamente nova na economia brasileira que era a preponderância do setor ligado ao mercado interno no processo de formação de capital. A p:ecária situação da economia cafeeira que vivia em regime de destruição de um terço do que produzia com um baixo nivel de rentabilidade, afugentava desse setor os capitais que nele ainda se formavam" (158).

Esse processo delineia-se com mais firmeza nos fins da década mas o contínuo aumento de meio circulante verificado a partir de 1934 e a baixa do poder aquisitivo no exterior serão estímulos da indústria paulista, que entre aquela primeira data e 1938 cresce cerca de $80 \%$. $\mathrm{O}$ consumo de energia elétrica da cidade de São Paulo demonstra-o eloquentemente: de $246.022 .904 \mathrm{kw}$ passa a 397.405 .080 no período mencionado (159).

O parque industrial paulista colocava-se muito acima dos que ostentavam as demais unidades da Federação representando pouco mais de $40 \%$ do valor total produzido no Brasil em 1938. Nesse ano a sua produção fora de 5 milhōes de contos de réis para 2.400 mil contos daquele situado imediatamente abaixo, o Distrito Federal (160).

Até então fora a indústria auxiliada pela inflação e elevação de tarifas, sem uma intervenção mais direta ou uma política mais orientada para o setor por parte do governo federal. Ao invés disso, medidas foram tomadas que afetaram alguns industriais como o tributo de $8 \%$ sobre os lucres remetidos para o exterior que, a despeito de seu carater nacionalista não fazia distinçōes precisas entre estrangeiros em geral e aqueles aqui residentes e que aqui reinvestiam seus lucros como os Jafet e os Matarazzo (161).

Com o Estado Novo abandonar-se-ia de vez o liberalismo político e pender-se-ia para um maior dirigismo econômico. Em discurso pronunciado em abril de 1938, Getúlio Vargas observaria que o valor por tonelada das exportações brasileiras declinava continuamente ao passo que os preços das importações continuavam os mesmos

- "disse se seguia que o país teria de começar a substituir os produtos importados por produtos de fabricação nacional" (162).

(158) . - Celso Furtado, Formaçāo Econômica do Brasil, Edição da Universidade de Brasília, 1963, p. 244.

(159). - Roberto C. Simonsen, ob. cit., p. 28/29.

(160). - Idem, ibidem p. 49.

(161). - Warren Dean, ob. cit., p. 199.

(162). - Idem, ibidem, p. 223. 
A alteração na concepção das prioridades seria um fator de estímulo a mais para a industrializaçāo, continuando São Paulo com meIhores condições para seguir à testa do processo, acelerado a partir da segunda guerra mundial, a despeito das dificuldades do período para a importação de equipamento e matérias-primas.

Dessa época em diante a indústria paulista sofreria grandes alterações, ampliando-se continuamente a diferença entre o valor da produção industrial e o da agrícola. Se em 1928-32 esta representava 58,8\% do total e a industrial $41,2 \%$, em 1935 essa relação já se invertera. Nesse ano o índice da produção industrial era de $53 \%$ e o da agrícola de $47,0 \%$, alargando-se rapidamente a diferença. Em 1940 eram respectivamente de $72,8 \%$ e $27,2 \%$ e em 1950 , de 80 e $20 \%$.

Sendo fundamentalmente de transformação, essa indústria de início, dedicou-se à fabricação de bens de consumo não duráveis ou semi-duráveis; em 1938 representava a indústria textil $24 \%$ da produção em São Paulo, a alimentícia cerca de $22 \%$, e $13 \%$ a da preparação de metais, fabricação de máquinas, aparelhos e instrumentos (163) .

Estavam ausentes dessas porcentagens as indústrias pesadas e básicas. Em 1950 os tradicionais setores textil e alimentícios ainda representavam $47,41 \%$ da produção industrial paulista caindo tal proporção para $31,07 \%$ em 1960 .

Setores mais modernos como o da metalurgia e da química cresceriam e far-se-ia sentir a fabricação de bens de produção, verificando-se o maior incremento na indústria automobilística. De 1969 a 1973, segundo os dados oficiais e atendendo à orientação da política econômica, a indústria de veículos cresceu no Estado, em média, $20,8 \%$ ao ano; a de tratores, $25,5 \%$; a de pneus $18,2 \%$, a de câmaras de ar, $21,6 \%$ (164). Todavia, a crise que se observa no mundo atual devido à questão do petróleo poderá atuar como freio à expansão desse setor.

Segundo a Secretaria do Planejamento Estadual, a produção industrial aumentou de $80 \%$ nos últimos 5 anos, inserida em uma expansão que apresentou em 1973

"o resultado mais expressivo da economia paulista no decu-so da última décađa" (165).

(163). - Roberto C. Simonsen, ob. cit., p. 29.

(164). - "Cinco anos de economia paulista", Jornal da Tarde de 10 de janciro de 1974.

(165). - Idem. 
No decorrer desse crescimento um outro fenômeno se destacará: o predomínio das sociedades industriais por açōes que acabarão por superar estatisticamente as empresas individuais. Decorreu do aumento e complexidade do sistema industrial, a exigir grandes capitais e sofisticadas técnicas, que não podiam depender da aventura individual. Todas essas circunstâncias acrescentarão novos segmentos à burguesia industrial que após a segunda guerra

\footnotetext{
"ascende definitivamente, superando totalmente o predomínio social e político das classes agrárias" (166).
}

A partir ainda do final da década de 40 aumentará o fluxo de capital estrangeiro no setor. Atraidas pelo mercado em expansão, companhias alienígenas transformam suas agências de vendas em filiais de operações manufatureiras. Respondiam ainda a uma política oficial que, para contornar o problema do balanço de pagamentos, oferecia incentivos, para o aproveitamento dos quais. necessitavam elas de sócios brasileiros. O efeito do movimento é relevante:

"no princípio da década de 60 metade talvez do capital industrial privado de São Paulo, com exclusão das oficinas de artesão, achava-se sob o domínio ou controle de estrangeiros" (167).

A composição social da burguesia industrial será outra então, tendo desaparecido a maior parte dos empresários pioneiros cuja atividade caracterizava-se pelo sistema de domínio pessoal e familiar, qual o primeiro Matarazzo.

Concomitantemente com o desenvolvimento industrial, aumentaria a força de trabalho numa correlação exaustivamente assinalada pelos dados disponíveis: segundo os Censos nacionais de 1940 e 1950 havia no Estado respectivamente 14.225 e 25.016 empresas industriais com 272.865 e 488.633 empregados. Um arrolamento organizado pelo Departamento de Estatística do Estado de São Paulo aponta 33.969 estabedecimentos e 793.844 empregados para o ano de 1958. Em 1960 já haveria em São Paulo 922.294 trabalhadores industriais, total de que se excluiam os trabalhadores nos transportes e operários da construção civil (168).

$\mathrm{O}$ aumento da força de trabalho está diretamente ligado às duas fases de crescimento industrial no período em análise. Teriam a demarca-las a Segunda Guerra Mundial

(166). - Edgard Carone, Oligarquias e classes sociais, p. 85.

(167). - Warien Dean, ob. cit., p. 254.

(168). - Aziz Simão, ob. cit., p. 14. 
- "embora antes dela se tenha verificado um quase ininterrupto aumento do número de estabelecimentos e da população operária, foi durante o seu curso e particularmente após o seu término que se acentuou de modo altamente expressivo o rítmo do referido processo econômico" (169).

Os dados relacionados por Aziz Simão enfatizam a afirmação: se de 1933 a 1937 o número médio anual de estabelecimentos criados foi da ordem de 500 , no primeiro quinquênio da década de 40 seria de 900 e 2.500 aproximadamente entre 1945 e 1949 . De 1950 a 1954 instalaram-se 13.600 novas firmas industriais, numa média anual de 2.700 .

A força de trabalho corresponderia a essa progressão. No primeiro quinquenio mencionado (1933-1937) os ingressos anuais foram da ordem de 15.000 . De 1950 a 1954 subiriam para 35 mil pessoas perfazendo um total de 184 mil no periodo.

Em relação ao Brasil essa mão-de-obra em 1950 correspondia a 1/3 aproximadamente do total: 484.844 operários em São Paulo para $1.256 .807 \mathrm{em}$ todo o território nacional.

A composição do operariado acompanhou o desenvolvimento da indústria e suas transformaçōes estruturais. A diversificação e mecanização ocorridas após a Segunda Grande Guerra incluem o aumento do tamanho médio de estabelecimentos e a produção de toda uma vasta gama de artigos, desde bens de consumo até os de capital.

Enquanto a indústria pioneira empregava predominantemente artesãos e pessoal não qualificado, imigrantes em grande parte, muitos destes desviados da lavoura de café, a do período posterior passou a utilizar pessoal semi-especializado para o manejo das máquinas e pessoal de nivel técnico para a supervisão da produção.

Como é de se presumir as relações de trabalho e produção tornam-se mais complexas, emergindo do processo a classe do operariado, com novas reinvindicações e diferentes formas organizatórias.

Já em novembro de 1930, quando as novas forças políticas se firmam no poder

"o operariado paulista manifesta-se contra a grave situação econômica, o desemprego, etc., mostrando que seus problemas não se identificam com os das classes dominantes" (170) .

(169). - Idem, p. 15.

(170). - Edgard Carone, Oligarquias e classes sociais, p. 108. 
O movimento grevista atuante é interrompido com o estado de sítio motivado pela revolução paulista de 32 , e depois diminui, com a recuperação industrial, que se observa a partir de 34 e com a instalação do Estado Novo.

Nessa década entretanto o ponto alto da luta operária seria a ação contra os integtalistas, agremiação de direita que, de pequena importância nos anos vinte, adquiriria maior notoriedade na década de 30 , influenciada pelo desenvolvimento do fascismo na Itália e do nacional-socialismo na Alemanha.

A culminância da ação operária contra o integralismo dar-se-ia com os acontecimentos da Praça da Sé em 7 de outubro de 1934 -

\footnotetext{
"Pela primeira vez o Sigma tenta fazer marcha espetacular em São Paulo e para isto são convocados adeptos de outros Estados" (171).
}

Os tiroteios e correrias que se seguem provocam a fuga dos integralistas, cuja propaganda perde o ímpeto inicial.

Quanto a medidas de proteção ao trabalho, criou o governo em fins de 1930 o Ministério do Trabalho, Indústria e Comércio que instalou em 1932 inspetorias regionais para os diversos Estados.

Em São Paulo, a União delegaria ao Estado atribuições que competiam às inspetorias regionais na área, com vistas à melhor execução da lei. A Inspetoria Regional a princípio e, posteriormente o Departamento Estadual do Trabalho, passariam a agir junto às associaçōes de empregados e empregadores com vistas à execução das leis trabalhistas.

Naquela década seriam aparentemente mais razoáveis as condições de trabalho e assistência social aos assalariados e, fato relevante, tais melhoras se dariam não mais como soluções dispersas e precárias mas numa "centralização das vias de solvência" em que se interpenetravam as ordens pública e privada.

Sindicatos, governo, patrões, iniciavam "a elaboração de novas vias institucionais de suas recíprocas relações", a consolidar-se com o correr do tempo. zeram

As associações sindicais multiplicaram-se e as mudanças se fi-

(171). - Idem, p. 126. 


\begin{abstract}
"no sentido de complexidade e burocratização, da concentração por setores econômicos, e da unidade, heteronomia e centralização organizatórias" (172).
\end{abstract}

Uma das mudanças seria significativa: de marginal ao Estado passou o Sindicato a integrar-se no próprio organismo estatal.

A expansāo econômica do Estado favoreceria o crescimento de sua população. Em 1934 o número de habitantes era de 6.433.327 (173). Seis anos depois, ou melhor, em 1940, o Estado abrigava 7.180 .316 pessoas e em 1950 cerca de 9.134 .423 , ou $17,4 \%$ da população brasileira de acordo com os dados censitários (174).

Não errariam os técnicos do Grupo de Planejamento do Departamento de Estatística do Estado ao preverem, em 1959, que daquela data em diante, a população cresceria à base de 500 mil habitantes por ano e passaria, dos 14 milhões existentes então a 17 milhões por volta de 1967 (175).

Realmente, o Censo de 1970 assinalou 17.775.500 habitantes no Estado de São Paulo (176).

A análise da composição dessa população revela que a época da imigração em massa de estrangeiros pertencia ao passado. Desde 1891 a entrada de imigrantes sempre fora superior a meio milhão. No entanto, entre 1931 e 1940 será de 218.607 elementos apenas (177), explicando-se a queda por várias razōes entre as quais a crise de 29 , o recrudescimento do nacionalismo em paises europeus, a formulação de leis brasileiras de proteção ao trabalhador nacional.

Entre 1930 e 1939 a imigração estrangeira seria alimentada principalmente por japoneses que em número de 101.666 superam de muito a das outras nacionalidades.

No período 1941-1949 entraram em São Paulo, em carater permanente, cerca de 45.518 estrangeiros com predominância de portugueses e italianos. Somente os primeiros superaram a casa dos dez mil (178). Em 1954 chegaram apenas 3.938 elementos do exterior (179).

(172). - Aziz Simão, ob. cit., p. 198.

(173). - Eurípedes Simões de Paula, ob. cit., p. 173.

(174). - A Gazeta de 30/6/1955.

(175) . - Christovam Dantas, "Conteudo econômico e demográfico", Diário da Noite, 24/3/1959.

(176) . - O Estado de São Paulo de 12/9/1971 ("Oitenta por cento dos paulistas são alfabetizados").

(177). - Edgard Carone, Oligarquias e classes sociais, p. 10.

(178). - 13.058 portugueses e 9.249 italianos (Boletim do Departamento de Imigração e Colonização, n 5, São Paulo, dezembro de 1950, p. 59) . (179). - O Tempo, 30/12/1954. 
Em relação à população global houve, entre 1940 e 1950 um decréscimo no número de estrangeiros da ordem de $3,4 \%$, correspondendo os 627.433 elementos existentes em 1950 a $6,6 \%$ da população total (180) e os 500.000 arrolados pelo Censo de 1970 a $3 \%$ apenas da população total (181) .

O crescimento observado no Estado a partir de 1930 dever-se-ia, a par do aumento natural, às correntes migratórias internas. De 1941 a 1949 entraram em São Paulo 431.153 brasileiros de outras regiōes e 45.518 estrangeiros somente. Os Estados que mais alimentaram o fluxo interno foram, pela ordem, Bahia e Minas Gerais e em escala menor Pernambuco, Alagoas, Ceará, Sergipe (182).

Só no ano de 1954 chegaram cerca de 96.436 nacionais (183), número que continuaria em ascensão nos anos posteriores.

Pode-se pois concluir que a imigração, nesse caso a interna, foi extremamente significativa para o aumento demográfico de São Paulo ho período em estudo já que o crescimento natural não teria sido suficiente para justificar os dados e índices mencionados acima. A porcentagem da população paulista atribuivel a incremento natural era em 1900 de $34,6 \%$ para a de $65,4 \%$ imputavel à imigração. Em 1960 a relação entre esses índices pouco se modificara: $36,1 \%$ e $63,9 \%$ respectivamente.

$O$ processo de industrialização acelerou o fenômeno da urbanização. Oferecendo oportunidade de fuga a uma baixa renda familiar e maiores possibilidades de consumo e investimento acentuou o fascínio quase hipnótico que as grandes cidades exercem sobre os adventícios e emigrados do campo.

Um dos indicadores da urbanização é a densidade da população citadina. A população urbana do Estado de São Paulo em 1970 era quase quatro vezes e meia maior que a rural: enquanto esta última acusava 3,5 milhōes a primeira girava em torno de 14.275.000 habitantes (184).

(180). - A Gazeta, 30/6/1955.

(181). - O Estado de São Paulo de 12/9/1971.

(182). - Boletim do Departamento de Imigração e Colonização, n 5 , 1950, p. $37 / 39$.

(183). - O Tempo, 30/12/1954.

(184). - $O$ Estado de São Paulo de 12/9/1971. 
Essa população tende à concentração - mais da metade dos paulistas vive no perímetro urbano de cidades com mais de 100.000 habitantes, cujo número passou de 7 para 18 no fim da década de 60 .

Os centros urbanos que oferecem razoavel índice de industrialização tem funcionado como polos de atração provocadores dos deslocamentos populacionais num movimento que já se vinha adensando na década de 40 , tomou inesperado vulto nos dez anos seguintes para assumir proporções inquietantes entre 1960 e 1970.

Assim é que no período de 1950 a 1960 a população dobrou, aumentando de $75 \%$ nos dez anos posteriores.

$O$ processo revela um esvaziamento generalizado da zona rural: se em 1960 esta continha $37,2 \%$ da população total, em 1970 esse índice caira para $22,7 \%$ o que representa uma queda de $16,9 \%$ em um decênio.

Em compensação a nopulação urbana apresentou um crescimento anual da ordem de $6,7 \%$ no mesmo período (185).

As grandes cidades tornam-se cada vez mais densamente povoadas e atraem em progressão crescente os elementos egressos do campo ou de núcleos citadinos menores.

A análise realizada por José Francisco de Camargo sobre o Recenseamento de 1970 assinala que Santos, por exemplo, sofreu um aumento populacional de cerca de $30 \%$ em um decênio. Há quatro anos atrás contava 354.456 habitantes, tornando-se a segunda mais povoada cidade do Estado, mas apenas $1 \%$ de sua população habita a zona rural.

Os municípios industrializados do Vale do Paraiba tambem apresentaram consideravel acréscimo populacional. São José dos Campos possuia 150.171 habitantes dos quais $90 \%$ na zona urbana e em Taubaté a população total aumentara de $40 \%$ enquanto a rural declinara $18 \%$.

Em Campinas, terceira cidade do Estado em população e um dos seus mais importantes polos econômicos a situação é semelhante, o mesmo ocorrendo em Ribeirão Preto e outros núcleos significativos, nos quais os índices de desruralização e de concentração urbana tornaram-se impressionantes.

Será em São Paulo no entanto que a concentração urbana se fará com maior intensidade, a ponto de provocar a advertência de um pre$6 / 6 / 1971$.

(185). - José Francisco de Camargo, ob. cit., O Estado de São Paulo de 
feito paulistano sobre a necessidade da cidade parar de crescer, tal a sua hipertrofia.

Após 1930 a Capital e suas vizinhanças continuaram a merecer a preferência das indústrias cuja localização permaneceu condicionada, no início, à proximidade das vias férreas e já agora à das rodovias.

A expansão industrial contribuiu para a formação e fortalecimento da Grande São Paulo, um fenômeno que os geógrafos chamam de conurbanização: os aglomerados vizinhos prolongaram suas áreas urbanizadas em direção a São Paulo enquanto esta avançava na direção daqueles, num encontro que já se realizou.

A região da Grande São Paulo que hoje em dia engloba mais de duas dezenas de municípios dos quais os mais importantes são os de Santo André, São Bernardo, São Caetano do Sul (a chamada zona do ABC), Diadema, Guarulhos, Mogi das Cruzes, Osasco, Mauá, abrigava em 1965 cerca de 1.320 estabelecimentos industriais que possuiam número de empregados superior a 100. Em 1968 trabalhavam ali 800 mil pessoas, das quais 650.000 diretamente ligadas à produção (186). Em 1970 a região agrupava $45,8 \%$ da população do Estado e $55,1 \%$ de sua população urbana.

$O$ alto índice de industrialização responderia pela predominância da população urbana. Só no $\mathrm{ABC}$ contavam-se nesse último ano ... 753.639 habitantes (187).

Mas é a Capital que apresenta índices configuradores de uma megalópolis: seus 5.901.533 habitantes perfazem mais de $70 \%$ da população total da Grande São Paulo (188) .

$\mathrm{O}$ acentuado crescimento das populaçōes urbanas geraria problemas que hoje refluem como boomerangs sobre essas mesmas populações. Exemplo? O da marginalização social. Nem sempre o mercado de trabalho tem a possibilidade de absorver a mão-de-obra que aflui resultando daí o desemprego, primeira etapa da marginalizaçāo.

$O$ fenômeno que já se generaliza nos maiores centros urbanos do Estado tem se tornado cruciante na Capital: prostituição, mendicância, crimanalidade aumentam em assustadora proporção.

A expansão tornou a estrutura urbana de São Paulo irregular e desordenada, contribuindo para tanto os loteamentos periféricos e as construções desenfreadas, numa especulação imobiliária notada já na

(186). - Pesquisa do Setor Industrial da Grande São Paulo, vol. II, São Paulo, Secretaria de Economia e Planejamento, 1969.

(187). - J. F. de Camargo, ob. cit., O Estado de Säo Paulo de 6/6/1971. (188). - Idem, ibidem. 
década de 50 pelos estudiosos do assunto e vigorosamente denunciada então, sem resultados. Ao contrário, essa especulação se intensificou, provocando surtos como o de 1973 em que o artificialismo dos preços chegaria a motivar pronunciamentos do governo federal.

Decorrente da especulação imobiliária é a acentuação da característica que fez São Paulo peculiar em relação às demais cidades brasileiras: a "floresta" de arranha-céus. A princípio limitados à área central, onde hoje constituem um bloco maciço e impressionante, alcançariam os bairros e avenidas em que anteriormente predominavam residências térreas ou quando muito assobradadas, como é o caso da Avenida Paulista, entre outros.

A fisionomia da cidade mudou, deixando de apresentar o aspecto fragmentário e estelar que se mantivera até o primeiro quartel do século presente.

A expansão da indústria automobilística superou de longe as previsões dos que tem por função orientar o desenvolvimento da cidade "que mais cresce no mundo", aumentando de maneira inquietante os índices de poluição atmosférica e sonora.

Tentativas de renovação dentro das modernas diretrizes do urbanismo foram executadas por alguns administradores no decorrer do período em estudo.

A primeira delas coube a Fábio Prado, prefeito de 1934 a 1938, em cuja administração dar-se-ia a fundação da Faculdade de Filosofia, Letras e Ciências Humanas da Universidade de São Paulo,

\footnotetext{
"marco bem definido de uma fase nova do desenvolvimento intelectual de todo o país".
}

Os prefeitos Francisco Prestes Maia, José Vicente de Faria Lima e mais recentemente o engenheiro Manuel de Figueiredo Ferraz preocuparam-se tambem com uma urbanização planejada e vinculada a uma orientação antes técnica que política. Tentaram arejar o Centro e desafogar o tráfego através da abertura de perimetrais e vias de irradiação e, como medida de maior porte iniciaram a implantação do Metropolitano que ainda se encontra em fase de construção.

Caberia novamente em face do gigantismo da Capital a indagação feita em 1930 por Domênico Bartolotti:

- "o que se tornará esta cidade em contínua renovação e desenvolvimento?" - Será "esta espécie de elefantíase explicavel e justificada"? (189) .

(189). - Apud Pasquale Petrone, ob. cit., p. 169. 
E no entanto é provavel que a disparidade de crescimento da cidade em relação ao de outras do Estado seja menor que aquele observado entre São Paulo e as demais unidades da Federação. Com um dado apenas já se poderá justificar a afirmação: o dos orçamentos estaduais que, apontando as receitas e despesas das unidades federativas espelham os índices da riqueza pública e das necessidades que o crescimento econômico motiva (190).

A estimativa do orçamento de São Paulo para 1975, de Cr\$ 34.421.739.523,00, coloca-o muito acima dos demais Estados, mesmo daqueles econômica e demograficamente mais importantes. E o caso da Guanabara, Rio Grande do Sul, Minas Gerais, Paraná, cujos orçamentos somados chegam a 33 milhōes aproximadamente, quantia inferior à do orçamento de São Paulo sozinho (191) .

Nada mais eloquente para ilustrar a liderança econômica do Estado. Esta, no entanto, não foi acompanhada com igual intensidade pela preeminência política.

A partir de 30 processa-se a centralização política-administrativa - retiraria o governo federal, gradativamente e em proveito próprio, a autonomia de que gozavam os Estados na República Velha e que fizera de São Paulo o polo hegemônico do país.

Esse processo que alcança os nossos dias sofreria breves períodos de arrefecimento como o de 1934-1937 e o de 1945-1964 sem contudo retornar-se ao sistema descentralizado da Primeira República.

A revolução de 1930 , feita para combater o "esclerosamento oligárquico do sistema político brasileiro" exigia a urgente revisão desse mesmo sistema, mas como a natureza dos remédios propostos para a obtenção do fim colimado variava entre os diversos grupos que a articularam bem logo começariam as dissenções.

Subindo ao poder procedeu Vargas à substituição dos governadores estaduais, colocando em São Paulo o então capitão João Alberto como delegado do governo provisório mas

(190). - Não obstante necessitem ser encarados com as devidas reservas, uma vez que ap:esentam distorções provocadas pelo erro de superestimar as receitas, misturar despesas de manutenção às de expansão, etc., oferecem boa margem de comparação.

(191). - Guanabara: $7.311 .289 \mathrm{mil}$; Rio Grande do Sul: $6.259 .691 .600,00$ Minas Gerais: 7.686 milhöes com um déficit de 1.776 milhõ்es; Bahia: 4.661 milhôes. Os demais Estados disporão de um orçamento menor (Cf. O Estado de São Paulo de 4/10/1974). 
"ao invés de tirar São Paulo das mãos inábeis e estranhas de João Alberto entregando-o a um paulista e civil insistiu e nomeou aquele militar interventor..." (192).

Infligia assim o primeiro arranhão na armadura do brio paulista, pois rompia o compromisso assumido com o Partido Democrático que o apoiara e que desejava o Prof. Francisco Morato na presidência do Estado. Outros se sucederiam: a nomeação de militares alheios aos problemas do Estado continuaria, o que, aos olhos de muitos paulistas significava intoleravel humilhação, que se desafogava em metáforas desabridas como a que comparava São Paulo à locomotiva que puxava os vinte vagões de carga vazios dos outros Estados e que expressava a indignação sentida então.

O controle federal se tornava evidente: a despeito das compras de café feitas pela União terem evitado a ruina total dos fazendeiros, as medidas subsequentes desagradavam-lhes. Os impostos estabelecidos eram vistos como confisco, temendo os agricultores novas exigências aos seus rendimentos.

Interventor civil e paulista tornou-se a palavra de ordem.

Rompe o Partido Democrático com o governo federal e constitui, em fevereiro de 1932, com o Partido Republicano, até então seu inimigo irreconciliavel, a Frente Unica Paulista, com o objetivo de "entregar São Paulo a si mesmo".

A nomeação de Pedro de Toledo, "paulista e civil" para o cargo de interventor pode ser considerada uma vitória. A posse de um secretariado imposto pela Frente Unica seria outra. Mas não bastaram.

"Constituição", "autonomia", "legalidade" são as palavras que do recinto fechado das agremiações políticas ganham as ruas, proferidas por todos.

Ao numeroso grupo que compunha o Partido Democrático afigurava-se patente que só as eleições imediatas e a reconstitucionalização do país preservariam uma porção da grande independência política de que havia gozado o Estado desde a década de 90. Parecia-lhes ainda que Vargas procrastinava a realização de eleições retardando assim o que lhes parecia o principal objetivo da Aliança Liberal e da revolução de 30: uma representação mais autêntica obtida pelo voto honestamente supervisionado e apurado.

(192). - Aureliano Leite, "Nota sobre Causas e objetivos da revolução de 1932", Revista de História, $\mathrm{n}^{\circ}$ 51, p. 142. 
Somente a Constituição traria a segurança da autonomia e da realização dos objetivos desejados e para tanto, se preciso fosse, chegar-se-ia à rebelião armada .

A aliança que a Frente Unica procurou com a oposição de outros Estados, particularmente Minas Gerais e Rio Grande do Sul sofre vacilações e impasses que a desgastam e retardam.

São Paulo precipita os acontecimentos desencadeando a revolução a 9 de julho de 1932:

"O fato é inesperado e torna-se singular. A pressão do governo federal e o receio de uma nova situação revolucionária leva o situacionismo de Minas Gerais e Rio Grande do Sul a apoiar Getúlio Vargas. A revolução estava derrotada" (193).

Não sem antes ter mobilizado a burguesia agrária e industrial, esta última liderada por Roberto Simonsen que coloca o parque industrial paulista a serviço da causa revolucionária.

$O$ interventor Pedro de Toledo seria proclamado governador a 10 de julho. Nesse mesmo dia $O$ Estado de São Paulo estampava em toda a sua primeira página as informaçōes sobre a revolta irrompida na madrugada anterior. Sob o título

$$
\begin{aligned}
& \text { "Está vitorioso em todo o Estado o movimento reviolucionário } \\
& \text { de carater constitucionalista" }
\end{aligned}
$$

informava que àquela altura já haviam aderido as guarnições federais sediadas em São Paulo. Realmente foi o que ocorreu. A elas se juntariam um forte contingente de Mato Grosso e a quase totalidade da Força Pública Estadual. Batalhões de voluntários formaram-se imediatamente e os 50 mil homens mobilizados foram comandados pelo então coronel Euclides de Figueiredo e posteriormente pelo general Bertoldo Klinger, até aquele momento comandante da região militar de Mato Grosso. A chefia suprema coube ao general Isidoro Dias Lopes.

Ao expor os motivos da luta a Proclamação então lançada retoma as queixas e reinvindicaçöes anteriores:

- "O Estado de São Paulo, na mais perfeita harmonia e solidariedade de civis e militares, sem lutas nem vozes discrepantes, não tem outros intuitos senão reintegrar o país na ordem legal e restituir aos brasileiros o gozo dos direitos e franquias que são o apanágio da nossa civilização" (194).

(193) . - Edgard Carone, A segunda República, São Paulo, 1973, p. 53.

(194). - Idem, Oligarquias e classes sociais, p. 312/313. 
A despeito do entusiasmo dos que participavam da luta e imaginavam não poder o governo federal resistir por muito tempo o evoluir dos acontecimentos apontar-lhes-ia a derrota. A eclosão prematura da revolta, quando as articulaçōes revolucionárias ainda se cingiam à fase preparatória e se ressentiam de um adequado suporte militar responde em parte pelo fracasso. A escassês de armamento, planos militares mal estruturados e de pequeno alcance estratégico constituir-se-iam em alguns dos fatores.

O fim do movimento seria marcado, como em todas as revoluções, pela fuga ou prisão dos vencidos. São Paulo foi militarmente ocupado, ficando sob a interventoria do general Waldomiro Castilho de Lima. Os grupos dirigentes e vitoriosos preferem exilar os mais visados, entre os quais encontravam-se nomes como os de Guilherme de Almeida, Prudente de Morais Neto, Francisco Morato, Júlio de Mesquita Filho, Paulo Duarte, Ibrahim Nobre, Aureliano Leite.

Aspirando a "entregar São Paulo a si mesmo" a revolução de 32 buscava recobrar a liberdade de ação facultada ao Estado no regime anterior. Não se pode no entanto considera-la a "contra-revolução dos oligarcas do antigo regime" como foi algumas vezes impropriamente rotulada.

A confusão deveu-se provavelmente ao apôio que lhe foi dado pelos políticos da República Velha, representados por Borges de Medeiros no Rio Grande do Sul, Artur Bernardes nas Minas Gerais e o Partido Republicano em São Paulo. Mas não seria demais lembrar que foi de fato o Partido Democrático, com o entusiástico endosso da classe média o organizador da conspiração e do movimento (195).

Um breve interregno pareceu sustar o processo centralizador. Se os revolucionários paulistas foram militarmente derrotados, conseguiram no entanto o atendimento ao seu objetivo político primeiro: a restauração da ordem constitucional.

\section{Getúlio Vargas}

"com a sua vocação civilista e o seu espírito de desgastar as forças que pudessem romper com a ordem social, pōe-se ao lado da reconstrução constitucional, talvez temeroso de que se desencadeasse um estado crônico de conflitos militares, ou mesmo civis" (196).

(195). - Thomas Skidmore, Brasil: de Getúlio a Castelo (1930/1964). Rio de Janeiro, 1969.

(196) . - Apud João Cruz Costa, Pequena História da República, Rio de Janeiro, 1968, p. 127. 
Convoca eleiçōes para a Assembléia Constituinte e permite o retorno dos exilados, que reassumem a direção da política estadual.

Elementos dos Partidos Republicano e Democrático compõem uma chapa única para integrar a Assembléia Constituinte.

A pacificação parece completar-se com a nomeação do "civil e paulista" Armando de Salles Oliveira, diretor de $O$ Estado de São Paulo, para o cargo de interventor federal, ocasião em que este, teria a seu crédito a criação da Universidade de São Paulo a 25 de janeiro de 1934.

Da convocação e instalação da Assembléia Constituinte, resultaria a Constituição de 14 de julho de 1934 que restabeleceu eleições diretas para a presidência da República .

Após a aprovação da Constituição Estadual Armando de Salles Oliveira torna-se governador, renunciando ao cargo em dezembro de 1936 para candidatar-se à presidência da República por uma coligação de partidos: a U. D. B., sigla da União Democrática Brasileira.

Tudo levava a crer que São Paulo caminhava para nova projeção no cenário nacional mas encontrando-se o governador paulista em plena campanha eleitoral ocorre o golpe de 1937.

Na verdade, a ambígua composição de forças que preparara o movimento de 30 desfizera-se com rapidez. O tenentismo revolucionário de 22 e 24 desvaneceli-se. Muitos dos antigos oficiais voltaram às fileiras do Exército, outros ingressaram no novo jogo político.

$O$ entrechoque de idéias a que se assistia no Legislativo desgastava-lhe o poder, refletindo as divergências de valores e conceitos dos grupos políticos cujas formulações expressavam a maior complexidade das forças sociais.

Nazismo e fascismo exerciam então verdadeira fascinação sobre os cobiçosos do mundo.

A massa operária era ainda muito debil e pouco organizada; os extremismos geravam inquietação favoravel aos desígnios de Vargas.

Dessa conjuntura se aproveitaria ele e utilizando a experiência já obtida com o poder discricionário prepararia a transformação da estrutura do Estado. Conseguiu que

\footnotetext{
"as classes armadas, representadas por seu Ministro da Marinha e Ministro da Guerra exigissem do Parlamento o estado de guerra, sob pretensa ameaça comunista. Não havia ameaça comunista. Havia a falsificação de um plano atribuido ao comu-
} 
nismo, falsificação que fora feita dentro do próprio Palácio do Exército por um oficial integralista" (197).

A pressurosa aceitação da exigência pelo Parlamento já seria indicativa da sua fragilidade, aproveitando-se Vargas de tal circunstância para dissolve-lo.

Com o fechamento do Congresso Nacional a 10 de novembro de 1937 inicia-se a ditadura paternalista do Estado Novo.

Armando de Salles Oliveira é preso e exilado, os partidos políticos são dissolvidos e São Paulo volta ao regime das interventorias federais. Atuariam então como delegados da União os interventores Ademar Pereira de Barros e Fernando Costa, o primeiro, de 1938 a 1941 e o último, dessa data até 1945 .

A volta à légalidade representaria um hiato em alguns aspectos do processo centralizador. A queda de Vargas em 1945 permitiu o livre jogo das forças políticas, que se organizam obedecendo já às sensíveis transformações sócio-econômicas ocorridas.

Os partidos que se estruturam em âmbito nacional vão disputar em São Paulo uma clientela variada e diversa: a industrialização dinamizara os centros urbanos permitindo a formação de importante bloco de eleitores e a política torna-se um jogo mais aberto e menos previsivel.

Essas características e o sistema multipartidário que se implanta explicarão as coligações e os compromissos entre os partidos, mesmo os de posição ideológica antagônica. Assim é que Ademar de Barros, o primeiro governador a administrar São Paulo após o Estado Novo teria a sua eleição assegurada graças ao acordo feito entre o partido que criara, o Social Progressista (PSP) e o Partido Comunista Brasileiro ( $\mathrm{PCB}$ ), de grande força política e que logo seria extinto pelo governo federal.

Nesse período contudo mostrar-se-ia inutil a busca empreendida pelas elites para encontrar um modelo prático que substituisse o sistema oligárquico-federalista que vicejara na Primeira República, e a diretrize que permitira a instalação do Estado Novo. Não conseguiriam os brasileiros organizar-se em partidos de conteudo ideológico ou realmente representativos dos interesses dos diferentes grupos sociais em antagonismo, e o que se viu entāo foi

"a multiplicação indiscriminada de agremiações, visando unicamente à disputa desenfreada de uma clientela eleitoral, manobra-

(197). - Paulo Duarte, Visão, novembro de 1972, p. 29. 
da por um populismo de carater messiânico que acabou por desmantelar os partidos onde proliferavam os chefes e os chefetes na medida em que se esvaziavam como forças populares" (198).

Tais procedimentos, tornando o processo de representação popular cada vez mais irrealístico e tumultuário e gerando as distorçōes do ademarismo, janismo e janguismo, enfraquece-lo-iam de modo irremediavel.

Desta forma o período iniciado em 1946 com a eleição do marechal Eurico Gaspar Dutra, no qual, segundo a análise de Cruz Costa,

"começamos a sentir, sob nova e diferente fase, a preponderância militar na política"

atingiria uma culminância com o movimento de 31 de março de 1964 que, no dizer do então embaixador norte-americano Lincoln Gordon foi

"do ponto de vista dos Estados Unidos um dos mais notáveis fatos da segunda metade do século XX e merece assumir na história um lugar tão importante quanto o fim da guerra da Coréia, os inícios do plano Marshall ou a solução da crise dos foguetes soviéticos em Cuba".

A partir daí o processo iniciado em novembro de 1930 e, reforçado em 1937, é então extremado. O rompimento com o liberalismo đa Primeira República e a caminhada para o estatismo que levaria no entanto ao equacionamento de problemas nacionais de grande magnitude como os do petróleo, siderurgia e energia elétrica tem suas primeiras manifestações antes mesmo do Estado Novo. A intervenção na esfera econômica é visivel no setor da agricultura quando, com o Convênio Cafeeiro de 1935 os Estados cedem o controle de seu produto ao Departamento Nacional do Café.

A criação de novos orgãos federais como o Instituto do Açucar e do Alcool em 1933 e depois de 37 o do Mate, o do Pinho, etc., possibilita a ingerência da União em áreas sobre as quais os governos anteriores jamais tinham reclamado poderes.

Através do Ministério da Educação e Saude bem como do Ministério do Trabalho supervisionava o governo federal áreas vitais antes restritas à competência dos Estados, cujo poder se enfraquecia uma vez que as influências regionais só se poderiam efetivar através dos canais do governo central.

(198). - Thomas Skidmo:e, ob. cit., Rio de Janeiro, 1969, p. 8. 
Perdida tambem ficou a prerrogativa a que se habituara São Paulo de negociar diretamente empréstimos estrangeiros para melhoramentos públicos ou para o financiamento do café.

Assim a autonomia pela qual se bateram os revolucionários de 1932 comprometia-se inexoravelmente, simbolizado afinal o seu término pela queima a que procedeu Getúlio Vargas das bandeiras estaduais.

A centralizaçāo far-se-ia em todos os níveis: obedecendo aos ditames federais facilitariam os interventores o controle da vida político-administrativa dos Estados. O cerceamento das liberdades políticas implicava em rígida censura sobre a imprensa: a rebeldia resultava em violência como no caso de $O$ Estado de São Paulo, que fechado e expropriado em 25 de março de 1940 retornariá a seus donos somente cinco anos depois (199).

A perda de prerrogativas seria vivamente sentida em São Paulo onde a pujança econômica ressaltava mais vivamente a ironia da impossibilidade de dirigir o próprio destino.

As queixas e reclamos posteriores evidenciam-no à saciedade:

- "Não são apenas as leis com que a ditadura cerceou a liberdade dos cidadãos $\mathrm{e}$ outros direitos fundamentais do Homem que reclamam revisão... a intervenção do governo na produção e no comércio só acarretava prejuízos para a coletividade. Aí está por exemplo a cana de açucar. Possuimos no Brasil em vários Estados e sobretudo no Estado de São Paulo terras e usinas capazes de abastecer desse produto o país inteiro. Meteu-se porem o governo a dirigir a produção e o resultado foi uma calamidade..." (200).

E mais: O Senhor Getúlio,

"ainda pensa que isto aqui é um fundo de quintal do Catete como nos saudosos tempos da regência da Carta de 10/11 quando Săo Paulo humilde e súplice, não tinha voz ativa nos Conselhos do Poder...... (201).

Mas a "redemocratização" de 45 a despeito đa distensão política não provocou uma descentralização acentuada. Largamente ampliado por Vargas, o Executivo pouco se modificou e após o movimento po-

(199). - V. Paulo Duarte, "127 anos de Imprensa Paulista”, O Estado de São Paulo de 25/1/1954.

(200). - O Estado de Sáo Paulo de 6/1/1946.

(201). - O Estado de São Paulo de 20/10/1946. 
lítico-militar de 1964 alargou a sua esfera de ação, atingindo mesmo mais sensivelmente que antes o âmbito municipal: governos federal e estadual foram organizando uma série de exigências

"umas constitucionais, outras legais, criando normas e estabelecendo princípios que restringiram não só os recursos financeiros mas a própria autoridade e autonomia dos p:efeitos" (202).

Dificil se torna ao historiador a análise de um passado recente $\mathrm{e}$ de processos em curso de vez que ele, agente das mudanças tanto quanto seu espectador teme um envolvimento prejudicial à isenção e objetividade necessárias à reconstruçāo de um período histórico. Todavia, o principal valor revelado pelo tempo é a continuidade através das transformaçōes, a permanência de alguma identidade sob as mudanças. Nesse sentido é lícito dizer que no período em análise o processo centralizador iniciado em 1930 manteve a sua continuidade. Sofreador da autonomia estadual acenturia o que, a nosso ver, é uma característica da História paulista dessa fase: a assincronia entre o poder econômico de que São Paulo desfruta e o poder político de que não dispõe.

(202). - "Onde foi parar o velho poder?" Jornal da Tarde de 21/10/1974. 